2013

\title{
Commercialization of Innovations: An Overarching Framework and Research Agenda
}

\author{
Avimanyu Datta \\ Illinois State University, adatta@ilstu.edu \\ Richard Reed \\ Cleveland State University, r.reed68@csuohio.edu \\ Len Jessup \\ University of Arizona
}

Follow this and additional works at: https://engagedscholarship.csuohio.edu/bus_facpub

Part of the Technology and Innovation Commons

How does access to this work benefit you? Let us know!

Publisher's Statement

This article is (c) Emerald Group Publishing and permission has been granted for this version to appear here 10.1108/AJB-08-2012-0048. Emerald does not grant permission for this article to be further copied/distributed or hosted elsewhere without the express permission from Emerald Group Publishing Limited

\section{Original Published Citation}

Datta, A., Reed, R., Jessup, L. (2013). Commercialization of Innovations: An Overarching Framework and Research Agenda. American Journal of Business, 28(2), pp. 147-191.

This Article is brought to you for free and open access by the Monte Ahuja College of Business at EngagedScholarship@CSU. It has been accepted for inclusion in Business Faculty Publications by an authorized administrator of EngagedScholarship@CSU. For more information, please contact library.es@csuohio.edu. 


\title{
Commercialization of innovations: an overarching framework and research agenda
}

\author{
Avimanyu Datta \\ College of Business, Illinois State University, Normal, Mlinois, USA \\ Richard Reed \\ Monte Ahuja College of Business, Cleveland State University, \\ Cleveland, Ohio, USA, and \\ Len Jessup \\ Eller College of Management, University of Arizona, Tucson, Arizona, USA
}

\begin{abstract}
Purpose - The commercialization of innovation, which is key to entrepreneurial success, is a combination of several entrepreneurial activities. Building on research from fields of management, strategy, entrepreneurship, economics, and marketing, the paper summarized the extant literature to develop a framework of commercialization and an agenda for future research. The paper aims to discuss these issues.

Design/methodology/approach - Extensive review of literature, which was comprised of 194 articles across 62 journals in the fields of management, strategy, entrepreneurship, economics, and marketing.

Findings - The literature was categorized into six broad themes of entrepreneurial activities: sources of innovations, types of innovation, market entry (capabilities and feasibility), protection, development, and deployment. Most of the research papers that were reviewed were concentrated on single theme.

Practical implications - Given the identification of six key themes of entrepreneurial activity leading to the commercialization of innovations, research questions were posed as a means to move the research forward by integrating the themes.

Originality/value - This is the first paper in its kind to integrate 194 papers from 62 journals to provide a comprehensive framework of commercialization of innovations.

Keywords Commercialization of innovations, Innovation commercialization pathway, Innovation sources

Paper type Research paper

\section{Introduction}

Innovation is often described as the lifeblood of organizations and, within a corporate setting, the true value of innovation is manifested in outcomes such as commercialized products (Schendel and Hill, 2007). A firm's ability to commercialize innovations can help dominate current markets or develop newer markets, which contributes to continued industry leadership (Wallsten, 2000; Salamenkaita and Salo, 2002). Thus, success in commercialization of innovations is of strategic importance to firms (Nerkar and Shane, 2007).

Entrepreneurial activities surrounding commercialization of innovations often start with idea generation and end in product launch. However, estimates suggest that,
\end{abstract}


of every 3,000 new-innovation ideas, only one is commercialized into a successful product (Stevens and Burley, 1997). Therefore, it is clear that the generation of ideas is not sufficient to commercialize innovations. Despite this low probability of translating innovations into products, the need to successfully commercialize is crucial. Consequently, firms often find themselves aiming three to five years in advance at an elusive future new-product target (Grove, 1996; Burgelman et al, 2006). Further, globalization has put more pressure on firms to commercialize innovations and to expand into global markets (Huygens et al, 2001; Hamel and Getz, 2004). Such pressure generates an increased pace in innovating and commercializing, which not only helps the innovators to be successful but also raises the bar for the competitors.

Past research has connected the ability to successfully commercialize innovations with firm's capabilities (Damanpour, 1991; Pennings and Harianto, 1992; Dougerty and Hardy, 1996; McGrath et al, 1996; Teece et al, 1997), human resource practices (Scott and Bruce, 1994; Nerkar et al, 1996), the nature of top-management teams (Bantel and Jackson, 1989; Howell and Higgins, 1990) and the external environment within which the firm operates (Milliken, 1987; Keats and Hitt, 1988; Abrahamson and Rosenkopf, 1993; Wade, 1996; Wade and Hulland, 2004). Despite the need to understand how to successfully commercialize innovations, the literature does not provide an integrative framework.

The importance of innovation commercialization is evident in practice as well. In 2010a McKinsey survey estimated that only 39 percent of executives felt that their companies are good at commercializing new products. In the same survey, one-third of them identified innovation commercialization as one of the foremost challenges and 43 percent said the bigger challenges included choosing which ideas to move forward. Academic research echoes these sentiments. For example, Chiesa and Frattini (2011) argued that many products in hi-tech industries fail due to poor understanding of the commercialization process. Yet there is no clear understanding, in management theory and practice, of how commercialization decisions influence the market failure of new high-tech products (Chiesa and Frattini, 2011). When taken together, this evidence points to the fact that we need to better understand the process of innovation-commercialization. Therefore, in this work, we conduct a review of the literature to better understand the underlying themes, integrate the pertinent findings, and identify avenues for future research.

This paper makes two major contributions. First, we define and provide conceptual boundaries around commercialization of innovations via an overview of the broad range of literature that has addressed it, from which we identify six main themes: sources of innovations, types of innovation, market entry, which includes both capabilities and feasibility, protection, development, and deployment. Second, we highlight omissions in the existing literature, and identify and discuss the issues and questions that need to be addressed by future studies. For the purpose of this paper, we will focus mainly on product innovation and those processes that are geared towards developing a product. The importance of service innovation notwithstanding, it remains outside the scope of this work.

What is commercialization of innovation?

Belying the idea that commercialization of innovation is a simple construct are the multiple definitions, conceptualizations, and operationalizations that have emerged across studies. Commercialization of innovation refers to the activities required for 
introducing an innovation to market (Kelm et al, 1995; Narayanan et al, 2000; Kwak, 2002; Andrew and Sirkin, 2003; Nambisan and Sawhney, 2007; Nerkar and Shane, 2007). Nerkar and Shane (2007) measured commercialization of innovation as the early indication of commercialization, operationalized as the first sale of the target product or service. However, when an innovation is introduced in the market, only technology enthusiasts typically procure in the early stage, and such enthusiasts comprise less than three percent of the market (Moore, 1991, 2000). The larger mainstream market is comprised of pragmatists and conservatives, and hence a successful commercialization is one that captures this mainstream market (Moore, 2000). Reaching the mainstream market in this manner is often difficult, and the threshold for "successful" commercialization of an innovation will likely lie somewhere between these two extremes - single sale on the one hand and saturating the mainstream market on the other. We therefore define the ability to commercialize an innovation as a firm's capacity to bring a product into a market and reach the mainstream of the market beyond the initial adopters.

For the purpose of this paper we will focus mainly on product innovation and the processes that are geared towards developing a product. For instance, firms often patent a process in order ultimately to create a product, with an example being the process of brewing coffee. These processes lead to construction of an apparatus such as a better coffee maker ( 16 - pump espresso), which are then sold as products. Hence these processes fall within the scope of our work.

\section{Methodology for literature review \\ Review strategy}

We surveyed the theoretical and empirical studies in leading management, strategy, entrepreneurship, economics, and marketing journals to date. We first searched articles in the Web of Science, JSTOR, ABI/INFORMS, and EBSCO Host databases using the terms "commercialization" and "innovations" and their derivatives (e.g. commercial). We did not restrict ourselves to searching the abstracts; rather we included those search terms for the entirety of the articles. In order to capture a comprehensive view of the topic across fields, we did not limit our search to any set of specific journals. After removing the overlapping articles from the databases, we were left with 194 unique articles from 62 journals across all five disciplines of management, strategy, entrepreneurship, economics, and marketing.

In order to categorize the journals into disciplines, we looked into the scope and objectives of each of them. The ones that are categorized within clear disciplines had clear statements in their objectives tied to contribution within those fields. 12 journals, focusing mainly on innovations and technology transfer were termed as "interdisciplinary". Their scope and objectives had an interdisciplinary flavor inspiring contribution from multiple fields. Two journals, The American Joumal of Sociology and the IEEE Transactions on Engineering Management were categorized as "others." Table I shows the distribution of journals and citations across the disciplines. It also shows the number of articles by discipline, number of articles by journal, their respective citations and average citations per article. While most journals had only one article, the Strategic Management Joumal and Joumal of Management Studies had 29 and 20 articles, respectively. The Strategic Management Journal also had the most citations at 31,908 . Administrative science quarterly had the highest number of citations per article at 5,086. 
Table I.

Distribution of journals and articles actoss disciplines

\begin{tabular}{|c|c|c|c|c|}
\hline Discipline & Journal name & $\begin{array}{l}\text { No. of } \\
\text { articles }\end{array}$ & Citations & $\begin{array}{l}\text { Citations } \\
\text { article }\end{array}$ \\
\hline \multirow{13}{*}{$\begin{array}{l}\text { Economics journals: } 13 \\
(21 \%) \text { articles: } 23(12 \%)\end{array}$} & The American Economic Review & 5 & 3,975 & 795 \\
\hline & $\begin{array}{l}\text { Brookings Papers on Economic } \\
\text { Activity }\end{array}$ & 1 & 3,229 & 3,229 \\
\hline & Cambridge Joumal of Economics & 1 & 414 & 414 \\
\hline & The Economic Joumal & 1 & 6,244 & 6,244 \\
\hline & $\begin{array}{l}\text { Economics of Innovation and New } \\
\text { Technology }\end{array}$ & 1 & 449 & 449 \\
\hline & $\begin{array}{l}\text { Joumal of Economic Behavior } \\
\& \text { Organization }\end{array}$ & 1 & 739 & 739 \\
\hline & Joumal of Economic Literature & 2 & 7,996 & 3,998 \\
\hline & Joumal of Political Economy & 1 & 2,240 & 2,240 \\
\hline & Journal of Urban Economics & 1 & 1,217 & 1,217 \\
\hline & The Quarterly Joumal of Economics & 1 & 1,518 & 1,518 \\
\hline & RAND Journal of Economics & 5 & 5,641 & $1,128.2$ \\
\hline & Review of Economics and Statistics & 2 & 286 & 143 \\
\hline & $\begin{array}{l}\text { The Scandinavian Journal of } \\
\text { Economics }\end{array}$ & 1 & 0 & 0 \\
\hline \multirow{19}{*}{$\begin{array}{l}\text { Entrepreneurship } \\
\text { journals: } 2(3 \%) \text { articles: } \\
3(2 \%) \\
\text { Interdisciplinary journals: } \\
16(26 \%) \text { articles: } 55(28 \%)\end{array}$} & Journal of Business Venturing & 1 & 287 & 287 \\
\hline & Small Business Economics & 2 & 670 & 335 \\
\hline & Administrative Science Quarterly & 7 & 35,605 & $5,086.4286$ \\
\hline & Industrial and Corporate Change & 1 & 188 & 188 \\
\hline & Innovation Policy and the Economy & 1 & 26 & 26 \\
\hline & $\begin{array}{l}\text { International Journal of Technology } \\
\text { Management }\end{array}$ & 1 & 27 & 27 \\
\hline & $\begin{array}{l}\text { Joumal of Product Innovation } \\
\text { Management }\end{array}$ & 8 & 2,078 & 259.75 \\
\hline & The Journal of Technology Transfer & 2 & 26 & 8.6666667 \\
\hline & $\begin{array}{l}\text { Technological and Economic } \\
\text { Development of Economy }\end{array}$ & 1 & 1 & 1 \\
\hline & Long Range Planning & 1 & 2 & 2 \\
\hline & Managerial and Decision Economics & 1 & 3 & 3 \\
\hline & $R \& D$ Management & 2 & 0 & 0 \\
\hline & Research Policy & 14 & 1 & 1 \\
\hline & Research Technology Management & 2 & 372 & 186 \\
\hline & $\begin{array}{l}\text { European Journal of Innovation } \\
\text { Management }\end{array}$ & 3 & 22 & 22 \\
\hline & $\begin{array}{l}\text { International Journal of Innovation in } \\
\text { Digital Economy }\end{array}$ & 1 & 559 & 279.5 \\
\hline & $\begin{array}{l}\text { International Joumal of Strategic } \\
\text { Information Technology and } \\
\text { Applications }\end{array}$ & 1 & 3,229 & 201.8125 \\
\hline & $\begin{array}{l}\text { Technological Forecasting and Social } \\
\text { Change }\end{array}$ & 1 & 2,585 & $1,292.5$ \\
\hline & Technovation & 6 & 306 & 51 \\
\hline \multirow{3}{*}{$\begin{array}{l}\text { Management journals: } 22 \\
(36 \%) \text { articles: } 70(36 \%)\end{array}$} & Academy of International Business & 1 & 899 & 899 \\
\hline & $\begin{array}{l}\text { Academy of Management Executive } \\
\text { (1993-2005) }\end{array}$ & 1 & 6 & 6 \\
\hline & Academy of Management Journal & 7 & 3,984 & $\begin{array}{l}569.14286 \\
(\text { continued })\end{array}$ \\
\hline
\end{tabular}

The American Economic Review

Cambridge Journal of Economics

Cambridse Journal of Ec

Technology

Joumal of Economic Behavior

Organization

The Quarterly Joumal of Economics

journals: $2(3 \%)$ articles

$3(2 \%)$

Interdisciplinary journals:

Administrative Science Quarterly

.

Intemational Journal of Technology

Management

Management

The Journal of Technology Transfer

Technological and Economic

ment of Econom

Managerial and Decision Economics

R\&D Management

arch Policy

Management

International Journal of Innovation in

Digital Economy

Applications

Technological Forecasting and Social

Academy of International Business

1993-2006)

(conlinted) 


\begin{tabular}{|c|c|c|c|c|c|}
\hline Discipline & Journal name & $\begin{array}{l}\text { No. of } \\
\text { articles }\end{array}$ & Citations & $\begin{array}{l}\text { Citations/ } \\
\text { article }\end{array}$ & \\
\hline \multirow{19}{*}{. } & Academy of Management Review & 1 & 2,619 & 2,619 & \\
\hline & California Management Review & 1 & 668 & 668 & \\
\hline & European Management Journal & 2 & 311 & 155.5 & \\
\hline & The Executive & 1 & 63 & 63 & \\
\hline & $\begin{array}{l}\text { Global Business and Organizational } \\
\text { Excellence }\end{array}$ & 1 & 8 & 8 & \\
\hline & Interfaces & 1 & 425 & 425 & \\
\hline & $\begin{array}{l}\text { Intermational Journal of Operations } \\
\text { and Production Management }\end{array}$ & $\tilde{1}$ & 11 & 11 & \\
\hline & Joumal of Management & 1 & 3 & 1.5 & \\
\hline & Journal of Management Studies & 20 & 751 & 751 & \\
\hline & Journal of Workplace Learming & 1 & 2,255 & 112.75 & \\
\hline & Management Science & 15 & 57 & 57 & \\
\hline & Organization Science & 6 & 7,489 & 499.26667 & \\
\hline & $\begin{array}{l}\text { Production \& Operations } \\
\text { Management }\end{array}$ & 2 & 11,683 & $1,947.1667$ & \\
\hline & Sloan Management Review & 1 & 0 & 0 & \\
\hline & Intemational Business Review & 1 & 8 & 8 & \\
\hline & Joumal of Business Research & 2 & 120 & 120 & \\
\hline & Technology \& Investment & 1 & 5 & 5 & \\
\hline & $\begin{array}{l}\text { International Journal of Management } \\
\text { Practice }\end{array}$ & 1 & 959 & 479.5 & \\
\hline & $\begin{array}{l}\text { Joumal of International Business } \\
\text { Studies }\end{array}$ & 2 & 0 & 0 & \\
\hline Marketing journals: & Journal of Marketing & 2 & 262 & 131 & \\
\hline \multirow[t]{2}{*}{$3(5 \%)$ articles: $7(4 \%)$} & Joumal of Marketing Research & 4 & 1,159 & 289.75 & \\
\hline & Marketing Science & 1 & 10 & 10 & \\
\hline \multirow{2}{*}{$\begin{array}{l}\text { Others journals: } 2(3 \%) \\
\text { articles: } 2(1 \%)\end{array}$} & American Joumal of Sociology & 1 & 1,802 & 1,802 & \\
\hline & $\begin{array}{l}\text { IEEE Transactions on Engineering } \\
\text { Management }\end{array}$ & 1 & 27 & 27 & \\
\hline \multirow{3}{*}{$\begin{array}{l}\text { Strategy journals: } 3(5 \%) \\
\text { articles: } 33(17 \%)\end{array}$} & Strategic Management Joumal & 29 & 4 & 2 & \\
\hline & $\begin{array}{l}\text { Technology Analysis \& Strategic } \\
\text { Management }\end{array}$ & 2 & 31,908 & $1,100.2759$ & \\
\hline & Joumal of Management \& Strategy & 2 & 146 & 73 & Table I. \\
\hline
\end{tabular}

Categorizing the literature into broad themes

The transformation of innovations into tangible products entails:

- Discovery. Recognizing a market for an innovation.

- Development. Developing and manufacturing it as a product.

- Deployment. Selling/distributing the product through distribution channels (Teece, 1986; Mitchell, 1989; Teece et al, 1997; Ahuja, 2000a, b).

Thus, we initially classified the emerging literature into these three categories. After coding the articles into these themes, we found that three categories were not sufficient to classify all the 194 papers. To begin with, we found a significant number of papers (26) concentrated on the types of innovations, process vs product, radical vs incremental, 
architectural vs component. Further, some papers linked types of innovations with sources (Jaffe et al, 1993; Henderson and Cockburn, 1994; Christensen and Bower, 1996; Morgan and Berthon, 2008; Damanpour et al, 2009; George et al, 2012) and development (Jaffe et al, 1993; Dahlin and Behrens, 2005; Golder et al., 2008; Morgan and Berthon, 2008; Damanpour et al., 2009; George et al., 2012), thereby making the category impossible to ignore. About 20 articles concentrated on aspects related to market entry based on the capabilities of the firm and economic and technological feasibility. Most articles in this area were standalone articles, not linking with other themes. (Exceptions were (Kelm et al., 1995; Morgan and Berthon, 2008; Kim et al, 2011; Lo et al., 2012), where feasibility was linked with sources of innovations, and deployment and development (Kim et al, 2011; Lo et al, 2012)). The reasons for the inclusion of market entry were:

- the articles ranged across disciplines: management, strategy and marketing;

- most of them came from top outlets such as Academy of Management Journal, The Economic Joumal, Journal of Marketing Research, Journal of Management Studies, Management Science, Organization Science, Research Technology Management, The Strategic Management Journal, and Technovation; and

- market entry and feasibility analysis is paramount in determining the commercial potential of an innovation.

With 21 articles, innovation protection also emerged as a theme within the commercialization of innovations. While most of the articles concentrated on means of innovation protection, such as trademarks, patents and copyrights (Jaffe et al, 1993; Grindley and Teece, 1997; Jaffe, 2000; Shane, 2002; Alcacer and Gittelman, 2004; Ziedonis, 2004; de Laat, 2005; Hall et al, 2005; Lecocq and Demil, 2006), many linked protection with other themes such as innovation sources (Jaffe, 1986; Levin et al., 1987; Levin, 1988; Jaffe et al, 1993; Cassiman and Veugelers, 2002; Shane, 2002; Aldridge and Audretsch, 2010; Gambardella and McGahan, 2010; Datta et al, 2011; Link et al, 2011), innovation type (Jaffe et al., 1993; Dahlin and Behrens, 2005; Anokhin et al., 2011), development (Lowe, 1993; Garud et al., 2002; Shane, 2002; Aldridge and Audretsch, 2010; Gambardella and McGahan, 2010; Anokhin et al, 2011; Datta et al., 2011), and deployment (Lowe, 1993; Grindley and Teece, 1997; Datta et al., 2011).

Three more themes had therefore emerged from our interpretation of the existing literature. Before committing ourselves to the six themes we also consulted two industry experts - an entrepreneur and an angel investor. Both of them agreed on the exhaustiveness of the six categories. Accordingly, we categorized the literature across these six themes:

(1) innovation source;

(2) innovation type;

(3) market entry: capabilities and feasibility;

(4) protection;

(5) development; and

(6) deployment.

In terms of distribution of articles across themes, several articles corresponded to more than one theme. Thus, adding the articles belonging to a theme will produce a number higher than the total number of articles surveyed (194). The distribution of articles 
across themes were innovation source (89), innovation type (26), market entry (20), protection (21), development (94), and deployment (27). Figure 1 (part 1) summarizes this information. Out of the 194 articles, 135 corresponded to a single theme, only 41 articles corresponded to two themes, 12 articles to three themes, and only six articles addressed four themes. There were no articles that addressed five or more themes. Figure 1 (part II) summarizes this information. Table II shows how each article fared in terms of its presence across the six themes and the citation scores of each article.

In addition to distribution of articles and number of articles, we also looked at citations for each of the articles for impact. Figure 2 (part I) summarizes overall citations for each of the six themes. And, Figure 2 (part II) summarizes number of citations by number of articles across themes. Figure 2 (part $I$ ) is consistent with Figure 1 (part $I$ ), which shows that source and development got the maximum citations at 79,520 and 70,745 , respectively.
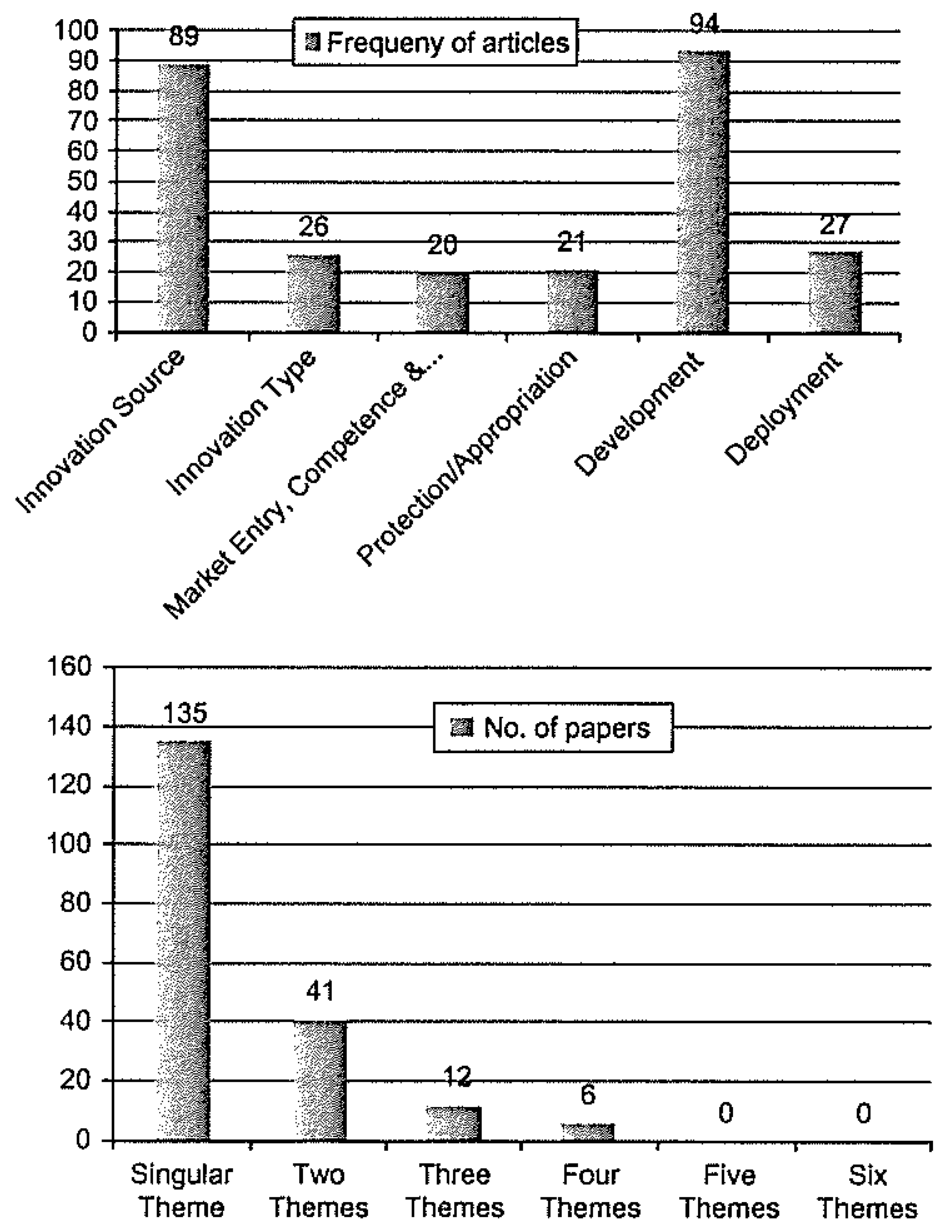

Note: Some Articles belong to more than one theme

Figure 1.

Frequency of articles by themes (I) and across themes (II) 


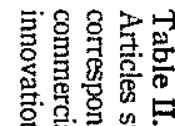

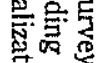

$$
\begin{aligned}
& \text { 请駕 }
\end{aligned}
$$

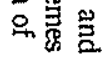

$$
\begin{aligned}
& \text { 马 }
\end{aligned}
$$

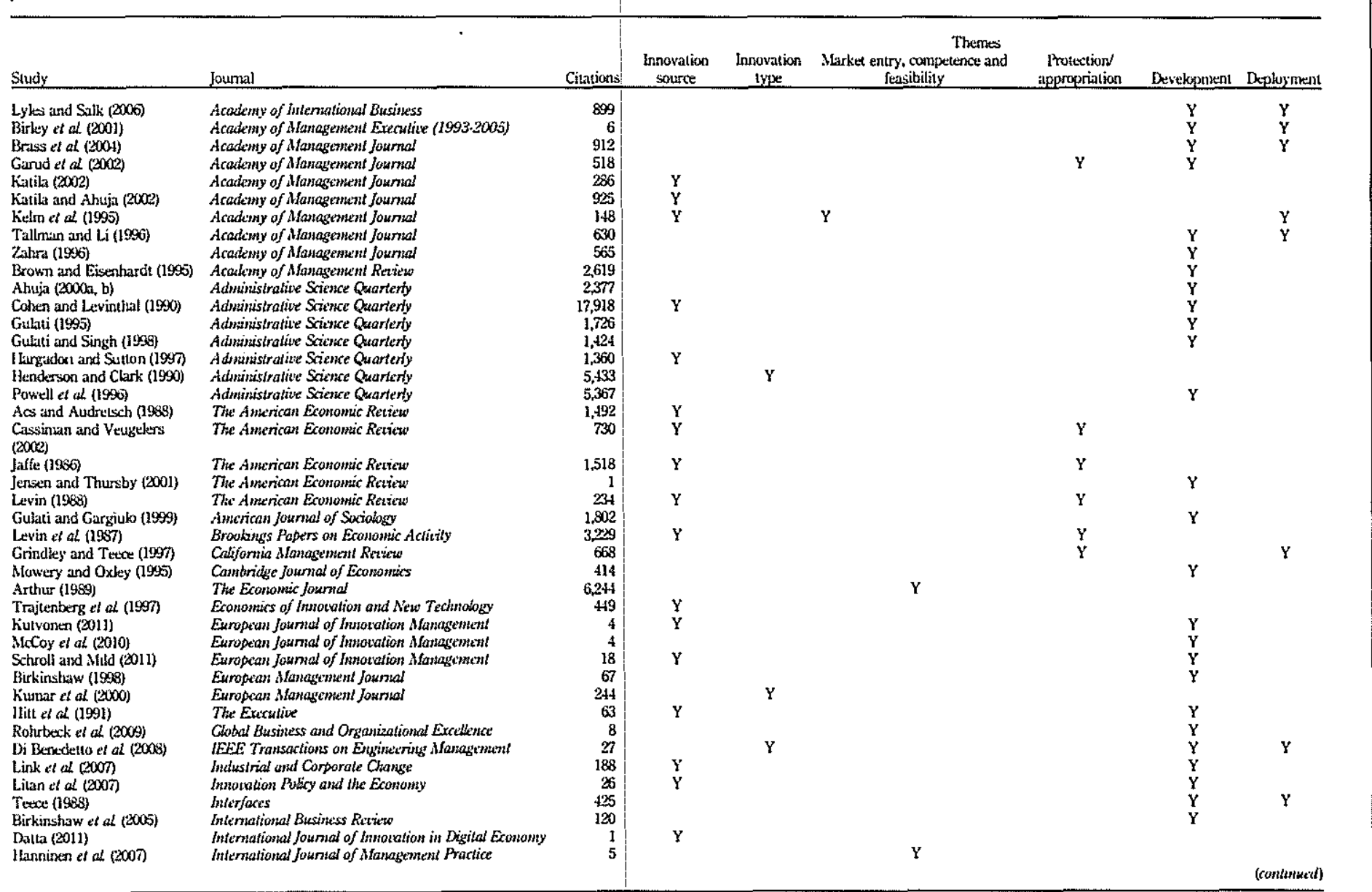




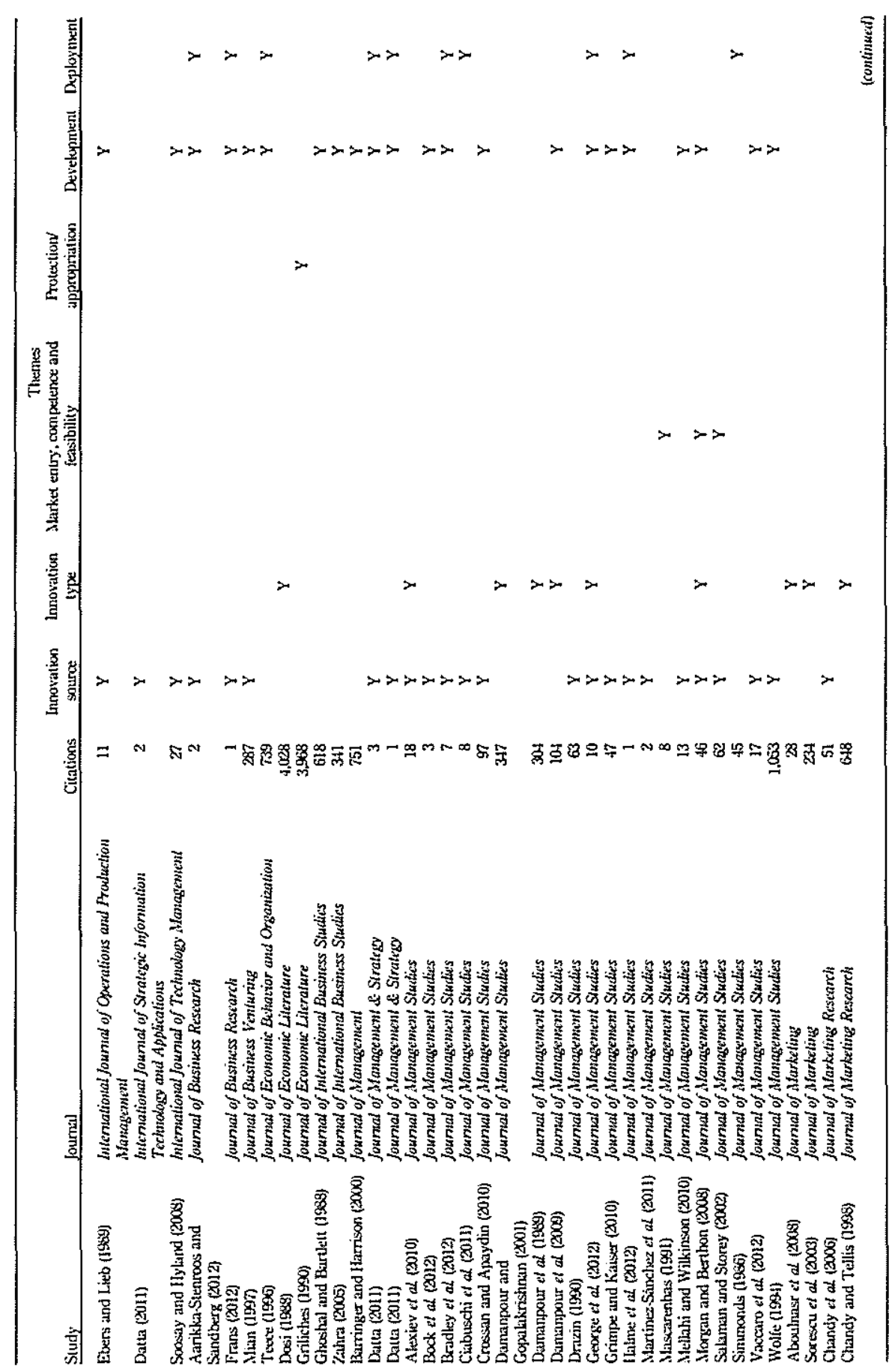

Table II. 


\begin{tabular}{|c|c|c|c|c|c|c|c|c|}
\hline Study & foumal & Citations & $\begin{array}{c}\text { Innovation } \\
\text { source }\end{array}$ & $\begin{array}{c}\text { Innovation } \\
\text { type }\end{array}$ & $\begin{array}{l}\text { Thumes } \\
\text { Starket entry, competence and } \\
\text { feusibibility }\end{array}$ & $\begin{array}{c}\text { Prolection } \\
\text { approprration }\end{array}$ & Deselopanent & Deplosiment \\
\hline $\begin{array}{l}\text { Filinstberg and Robertison } \\
(1958)\end{array}$ & Jounal of Marketing Restarch & 201 & & & & & & $\mathrm{Y}$ \\
\hline Shaunkar ef of (1998) & Jounal of Marketing Rescarch & 259 & & & $\mathrm{Y}$ & & & \\
\hline $\begin{array}{l}\text { Katz and Shapiro (1986) } \\
\text { Asthide of ol } 109606\end{array}$ & 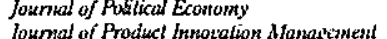 & 2,210 & & & $\mathbf{Y}$ & & & \\
\hline $\begin{array}{l}\text { Athaide el of (1996) } \\
\text { Cooper (1960) }\end{array}$ & 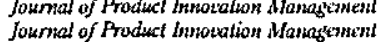 & ${ }_{196}^{119}$ & $Y$ & $\mathbf{Y}$ & & & $Y$ & \\
\hline $\begin{array}{l}\text { Cooper and Kkinschmidt } \\
01086\end{array}$ & Josnial of Product Intotalion Managzement & 805 & $\dot{Y}$ & & & & $\mathrm{Y}$ & \\
\hline $\begin{array}{l}\text { (1906) } \\
\text { Johne and Srelson (1988) }\end{array}$ & Journal of Product Imotution Management & 245 & & & & & $Y$ & \\
\hline Ragatz et al (1997) & Joumal of Product Imsonation slanagriment & 580 & & & & & $\mathrm{Y}$ & \\
\hline Slater and Moth (20006) & Jounnal of Product Innotation Masuagentent & 129 & & & & & & $\mathrm{Y}$ \\
\hline Spivey et al (1997) & Journal of Prodsct Innoration Managentes! & 39 & & $\mathrm{Y}$ & & & & \\
\hline Yoon and Lilien (1988) & Jountal of Product hnovation Mlanagentent & 15 & $Y$ & & & & & \\
\hline Berrovitz and Feidman (2006) & Jukmal of Teclunolug Transfer & 215 & $\mathrm{Y}$ & & & & & \\
\hline Wright at of (zoO4) & Jountal of Technology Transfer & 166 & $\mathrm{Y}$ & & & & & \\
\hline Ansedin et al (1997) & Joumal of Urban Ecostontiss & 1,217 & $\mathrm{Y}$ & & & & & \\
\hline Elmuti el all (2005) & Jountal of Workphace Lianingt & 57 & $Y$ & & & & & \\
\hline Brouthers et of (1993) & Long Range Panuning & 303 & & & & & $\mathrm{Y}$ & \\
\hline $\begin{array}{l}\text { Gambardella and MoGahan } \\
\text { (2010) }\end{array}$ & Long Range Plansing & 69 & $\mathrm{Y}$ & & & $\mathrm{Y}$ & $\mathrm{Y}$ & \\
\hline Alrovida and hogut (1999) & Mankz'ment Scinke & 1,5266 & $\mathrm{Y}$ & & & & & \\
\hline Cassimun and Vedia $(2000)$ & Manabentent Srience & 111 & & & & & $\mathrm{Y}$ & \\
\hline Clark (1959) & Manastement Scrience & 720 & & & & & $\mathrm{Y}$ & \\
\hline Coben $u t$ at $(2002 \mathrm{a}, \mathrm{b})$ & Markigement Srience & 1,247 & $\mathrm{Y}$ & & & & & \\
\hline Dutta and Weiss (1997) & Mangagement Scionke & 176 & & & & & $\mathrm{Y}$ & \\
\hline Griffin and louses (1992) & Manasement Srience & 503 & & & & & $\mathrm{Y}$ & \\
\hline Kulatilaka and Lin (2006) & Manngement Srienke & 32 & & & & & $\dot{Y}$ & \\
\hline Lilikn ef al (2002) & Managenest Srittce & 465 & & & & & $y$ & \\
\hline Liliken and Yocas $(1950)$ & Managemcnt Science & 333 & & & $Y$ & & & \\
\hline Ron and Levinthail (2001) & Management Srience & 350 & & $\mathrm{Y}$ & & & & \\
\hline Rosenkopf and Almeida & Managemtent Scionce & $60+4$ & $\mathrm{Y}$ & & & & & \\
\hline$(2003)$ & & & $\mathrm{y}$ & & & & & \\
\hline Schilling and Phelps (2007) & Management Srizzice & 290 & $Y$ & & & & $\mathrm{Y}$ & \\
\hline Slyane (2002) & Mandgement Science & 324 & $\mathrm{Y}$ & & & $\mathrm{Y}$ & $\mathbf{Y}$ & \\
\hline Urban et al (1986) & Managensent Sainse & 534 & & & $\mathrm{Y}$ & & & \\
\hline Zixdonis (2001) & Maragerhent Scionce. & 2055 & & & & $\mathbf{Y}$ & & \\
\hline Shaw and Shaw (193i) & Masuagerial and Decision Eronomics & $\mathscr{2}$ & & & $Y$ & & & \\
\hline Golder et ul. (2003) & Marketing Science & 10 & & $\mathrm{Y}$ & & & $Y$ & \\
\hline Alrovida et al (2002) & Orgartization Srience & 306 & $Y$ & & & & $\mathrm{Y}$ & \\
\hline Conner and Frahalad (1996) & Organization Science & 2,486 & & & $\mathrm{Y}$ & & & \\
\hline Hill (1992) & Organization Science & 79 & & & & $Y$ & & \\
\hline Kogut and Zander (1992) & Organization Science & 7,959 & $\mathrm{Y}$ & & & & & \\
\hline Sadhok and Talman (1998) & Orgunization Stratere & 657 & & & & & $\mathrm{Y}$ & $Y$ \\
\hline Pennings and likrianto (1992) & Organization Science & 196 & & & & & $\mathrm{Y}$ & (continust $)$ \\
\hline
\end{tabular}




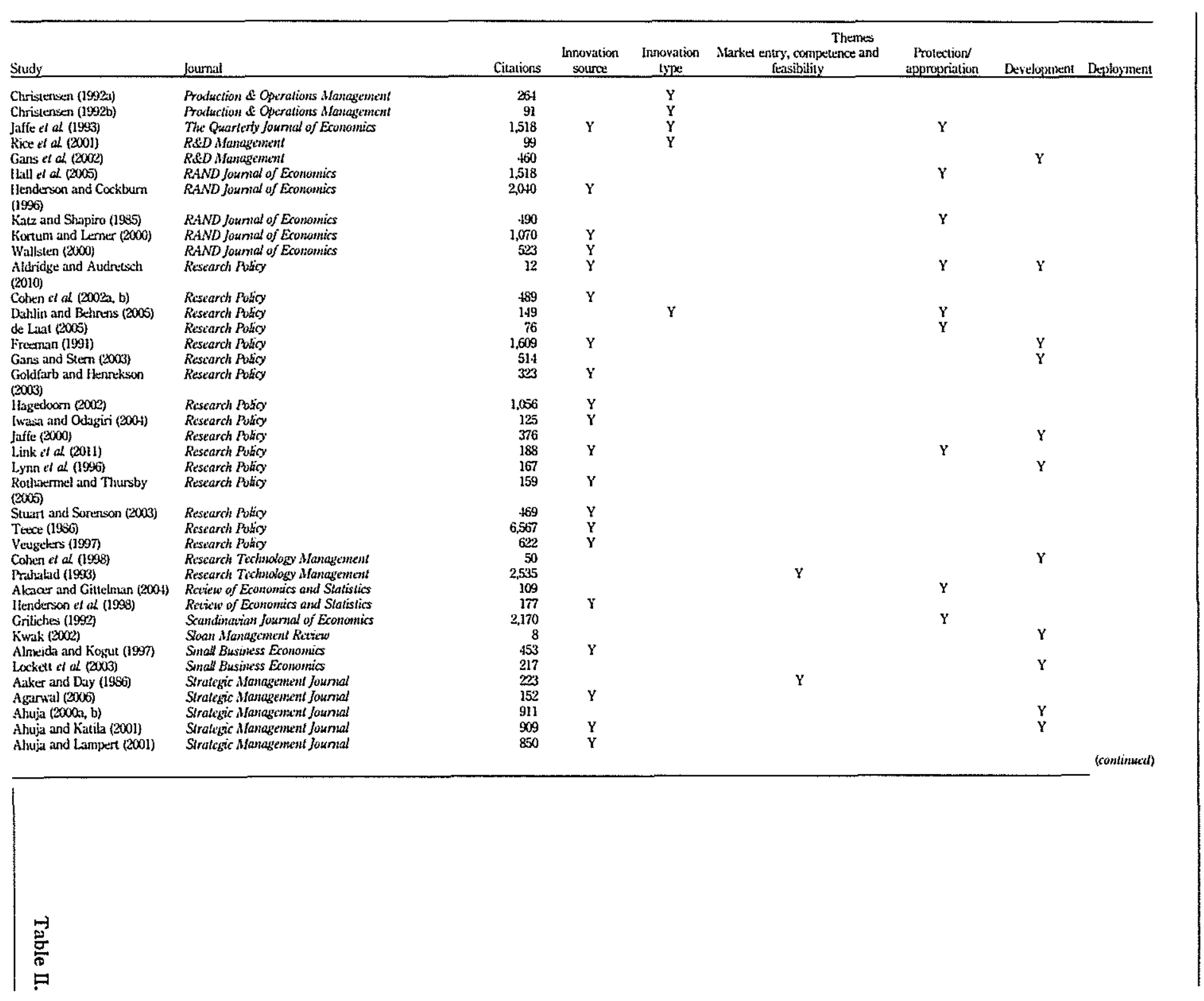




\begin{tabular}{|c|c|c|c|c|c|c|c|c|}
\hline sudy & Journal & Cintions & $\begin{array}{c}\text { Innovalion } \\
\text { soutree }\end{array}$ & $\begin{array}{c}\text { Innovation } \\
\text { lype }\end{array}$ & $\begin{array}{l}\text { Thernes } \\
\text { Market entry, cumpetence and } \\
\text { feasibility }\end{array}$ & $\begin{array}{c}\text { Protextion/ } \\
\text { appropristion }\end{array}$ & Develograkent & Deployment \\
\hline and and Whanna (2000) & Siratigic Management Jounnal & 1,333 & & & & & $\mathrm{Y}$ & \\
\hline ther (1988) & Strategic Mantagement Jounual & 88 & & & & & $\mathrm{Y}$ & \\
\hline Christersen and Bower (1996) & Straligic Management Jounat & 1,384 & $\mathrm{Y}$ & $Y$ & & & $Y$ & \\
\hline Jasnertis (2002) & Stralegic Manlogement Jountal & 891 & & $\mathrm{Y}$ & & & & \\
\hline yyer and Nobeotid (2000) & Strategic Mangement Joumal & 2.342 & $\mathrm{Y}$ & & & & & \\
\hline Gulusti (1958) & Sralegic Mangerement Joumal & 3,403 & & & & & $\mathrm{Y}$ & \\
\hline Gulati of al $(2000)$ & Stratigic Mfangement Jounal & 2,958 & & & & & $\mathrm{Y}$ & \\
\hline lagedoarn (1993) & Stratcigic Management Jounial & 1.773 & & & & & $\mathrm{Y}$ & \\
\hline $\begin{array}{l}\text { lenderson and Cockbusn } \\
\text { 1994] }\end{array}$ & Stralegic Management Journal & 2,040 & $\mathrm{Y}$ & $Y$ & & & & \\
\hline gat (1988) & Strutegic Management Jounzal & 3,083 & & & & & $Y$ & \\
\hline rokia and Prescott (3002) & Strattgic Mastasement Joursal & 557 & & & & & $Y$ & \\
\hline ane and Lubalkin (19938) & Stralegic Management Joursal & 2,858 & $Y$ & & & & & \\
\hline ecocq and Denil (2006) & Sfrategic Mantagement Jounal & 17 & & & & $\mathrm{Y}$ & & \\
\hline itberman and Mfontgontry & Strategic Marlasement foumal & 2371 & & & $\mathrm{Y}$ & & & \\
\hline Lakiadok (1993) & Strategric Nonagement Joumal & 256 & & & $y$ & & & \\
\hline lowery et al (1996) & Strategic Maraserement Joumal & 2282 & & & & & $Y$ & \\
\hline Narayaran ef al (2000) & Strafegic Mastagement Jourmat & 50 & $\mathrm{Y}$ & & & & & \\
\hline Verkair and Roberts (2004) & Strategic Management Journal & 199 & & & & & & $\mathrm{Y}$ \\
\hline Verkar and Shane (2007) & Stratestic Mangerement Jounsal & 62 & & & & & $\mathrm{Y}$ & \\
\hline $\begin{array}{l}\text { Tenser f lahn and Shaver } \\
2005 \text {. }\end{array}$ & Strategic Managament Jounaal & 169 & $\mathrm{Y}$ & & & & & \\
\hline Stasnsie et of (200-4) & Strategir Martasement Jounual & 83 & & & $y$ & & & \\
\hline xug et al $(2000)$ & Stratigric Manajertent Jounal & 242 & & & $Y$ & & & \\
\hline Zahra and Nielisen (2002) & Strategric Management Joannal & 31 & & & & & $Y$ & \\
\hline Clangyg and Li (20003) & Strategic Management Joumal & 61 & & & & & & $Y$ \\
\hline Lowe (1993) & Tecturdogy Anabsis \& Strategic Management & 65 & $Y$ & & & $\mathrm{Y}$ & Y & $\dot{Y}$ \\
\hline Salamenkith and Salo (2002) & Technology Anabsis \& Siralegic Management & 81 & $\dot{Y}$ & & & . & & \\
\hline Datta et oul (2011) & Technodosy \& Intestment & 0 & $\mathrm{Y}$ & & & $Y$ & $\mathrm{Y}$ & $Y$ \\
\hline Kim et al (2011) & Technolosical and Economic Detelopinent of Economy & 1 & $\mathrm{Y}$ & & Y & 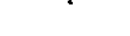 & $\mathrm{Y}$ & $\dot{Y}$ \\
\hline nokhin ef al (2011) & Technological Forceasting and Sactal Change & 3 & & $\mathrm{Y}$ & & $\mathrm{Y}$ & & \\
\hline utio (1991) & Technozation & 58 & $Y$ & & & & & \\
\hline yannis ef of (1998) & Terhnovation & 213 & & & & & $\mathrm{Y}$ & \\
\hline Chen and Guan (2011) & Tochnotation & 3 & & & & & $\Psi$ & \\
\hline Guan and Chen (2010) & Technoeration & 32 & Y & & & & Y & \\
\hline Loet at (z)12) & Techusutation & 2 & $\mathrm{Y}$ & & $\mathrm{Y}$ & & $\mathrm{Y}$ & $\mathrm{Y}$ \\
\hline Numprasertchai and Iged & Teclunotation & 64 & $\mathrm{y}$ & & & & & \\
\hline
\end{tabular}




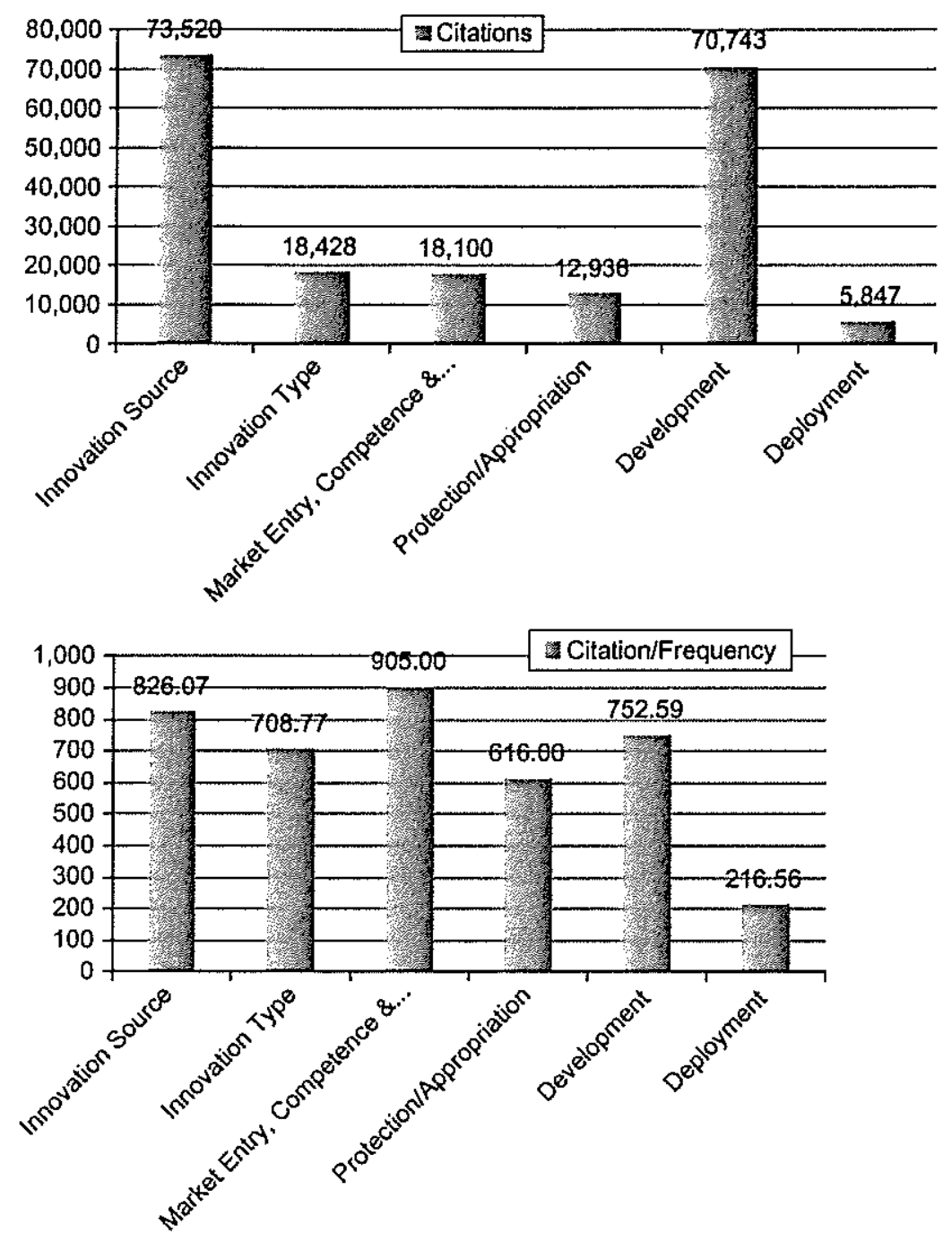

Figure 2. (I) Frequency of citations by themes and (II) frequency of citations/no. of articles by themes

Central themes in commercialization of innovation

For an easier assimilation of the six themes that lead to the commercialization of innovations, as depicted in the articles and journals we examined, we created Figure 3. It shows how the six themes fit into the main activities of discovery, development, and deployment that broadly describe the process of innovation-commercialization. We need to caution the reader here about what may appear to be linearity among the themes in terms of sources of innovation leading to types of innovation, which in turn lead to market entry, and so forth. We cannot and do not claim linearity in the order of these activities. Depending on the scope of an innovation, a manager of a project can simply start from deployment of a prototype, seek customer feedback, and develop 
Figure 3.

Entrepreneurial steps to commercialization of innovations: themes from the extant literature
Entrepreneurial Activities to Commercialize innovations

\begin{tabular}{|c|c|c|c|c|c|}
\hline \multicolumn{2}{|c|}{$\begin{array}{l}\text { Discovery: Market } \\
\text { Recognition for } \\
\text { Innovation }\end{array}$} & \multicolumn{2}{|c|}{$\begin{array}{l}\text { Development: Develop and } \\
\text { Manufacture the innovation into } \\
\text { goods }\end{array}$} & \multicolumn{2}{|c|}{$\begin{array}{l}\text { Deployment: Sell and } \\
\text { Distribute the Goods }\end{array}$} \\
\hline $\begin{array}{l}\text { Sources of } \\
\text { Innovations }\end{array}$ & $\begin{array}{l}\text { Types of } \\
\text { Innovations }\end{array}$ & $\begin{array}{l}\text { Market Entry } \\
\text { (Competence } \\
\text { \& Capability) }\end{array}$ & Protection & Development & Deployment \\
\hline $\begin{array}{l}\text { Organizational } \\
\text { Creativity }\end{array}$ & $\begin{array}{l}\text { Product Versus } \\
\text { Process }\end{array}$ & \multirow{2}{*}{$\begin{array}{l}\text { Entry-ine } \\
\text { Assossment \& } \\
\text { First Mover } \\
\text { Advantago }\end{array}$} & $\begin{array}{l}\text { Effoctiveness } \\
\text { of Protection }\end{array}$ & \multirow{3}{*}{$\begin{array}{l}\text { Design and } \\
\text { manufactudng } \\
\text { in-house vs. } \\
\text { collaboration }\end{array}$} & Launch Time \\
\hline \multirow{2}{*}{$\begin{array}{l}\text { Research and } \\
\text { Development } \\
\text { (R\&D) }\end{array}$} & $\begin{array}{l}\text { Radical Versus } \\
\text { Incremental }\end{array}$ & & $\begin{array}{l}\text { Protection } \\
\text { Versus }\end{array}$ & & \multirow{2}{*}{$\begin{array}{l}\text { Selling and/or } \\
\text { Licensing and } \\
\text { Compatbility }\end{array}$} \\
\hline & \multirow{4}{*}{$\begin{array}{c}\text { Architectural Versus } \\
\text { Component-based } \\
\text { innovallons } \\
\text { Competence } \\
\text { Enhancing Versus } \\
\text { competence } \\
\text { Destroying } \\
\text { Innovalons }\end{array}$} & \multirow{2}{*}{$\begin{array}{l}\text { Compotonco } \\
\text { Anatysis }\end{array}$} & Diffusion & & \\
\hline \multirow{2}{*}{$\begin{array}{l}\text { Alliances and } \\
\text { Collaborations }\end{array}$} & & & & \multirow{2}{*}{$\begin{array}{l}\text { Process of } \\
\text { developing the } \\
\text { innovation }\end{array}$} & \\
\hline & & & & & Pricing \\
\hline $\begin{array}{l}\text { Innovation } \\
\text { Engines }\end{array}$ & & & & \multirow{2}{*}{$\begin{array}{l}\text { Launch pad: } \\
\text { Spinout. } \\
\text { subsidtary, or } \\
\text { joint venture }\end{array}$} & Distritbution \\
\hline Technology & & & & & Marketing \\
\hline
\end{tabular}

Technology Spillovers

the innovation. Conversely, and for example, if the product is a therapeutic drug it is more likely that a more-linear process involving all six stages will be used.

All commentaries in the following sections are committed to the themes we identified rather than the order in which they take place. Below we describe the literature by the themes that emerged.

\section{Innovation source}

Innovation can originate within or outside the boundaries of the firm. The literature has identified sources of innovations as:

- organizational creativity;

- research and development;

- alliances and collaborations,

- innovation engines;

- technology clusters; and

- technology spillovers.

Organizational creativity. The creativity of the organization is a function of creative individuals and a variety of social processes and contextual factors that shape the way individuals interact and behave (Woodman et al, 1993; Schilling and Phelps, 2007). To maximize creativity and idea generation processes that subsequently translate ideas into products, firms have routines and incentives in place (Schilling, 2006). Firms with the highest conversion ability are those that first focus on a moderate number of ideas in areas of market importance and in which they have expertise, and, second, that deliberate for a moderate length of time on promising ideas (Roberts, 2001; Chandy et al, 2006). 
Research and development. Firms' R\&D intensity has been shown to have a positive correlation with sales from new products, sales growth rate, and profitability (Roberts, 2001). Thus, as a source of ideas for innovation, the R\&D function, whether internally funded or externally contracted, is key (Acs and Audretsch, 1988; Levin, 1988; Kelm et al, 1995; Veugelers, 1997; Lane and Lubatkin, 1998; Kortum and Lerner, 2000; Wallsten, 2000; Cassiman and Veugelers, 2002; Hagedoorn, 2002; Katila, 2002; Iwasa and Odagiri, 2004; Penner-Hahn and Shaver, 2005).

Alliances and collaborations. Recognition of an opportunity to commercialize an innovation is more likely to happen at the confluence of diverse entities (Anderson, 2008). Alliances and collaborations can help bring entities closer (Seppanen and Skates, 2001) through knowledge sharing and transferring. For instance, networks with customers, suppliers, complementors, and competitors are valuable sources of new product ideas (Cooper and Kleinschmidt, 1986; Yoon and Lilien, 1988). Also, external sources of information complements in-house R\&D thereby increasing a firm's absorptive capacity (Cohen and Levinthal, 1990; Lane and Lubatkin, 1998; Zahra and George, 2002; Chen, 2004). These sources include new ventures, licensing arrangements, sourcing agreements, research associations, and government-sponsored joint-research programs, as well as informal networks (Allen, 1977; Freeman, 1991; Hargadon and Sutton, 1997, 2000; Ahuja and Lampert, 2001; Burt, 1992). Such networks are especially important in high-technology sectors where it is unlikely that an individual firm will possess all the capabilities necessary to commercialize an innovation (Hagedoorn, 2002).

Innovations engines: universities and government. Universities and government agencies were freed to innovate with a view toward commercialization with the passing of the Bayh-Dole and the Stevenson-Widler Acts in 1980. Consequently, universities and firms will now often collaborate to develop innovations that can be commercialized (Trajtenberg et al., 1997; Carayannis et al, 1998; Jensen and Thursby, 2001; Goldfarb and Henrekson, 2003; Wright et al, 2004; Numprasertchai and Igel, 2005; Rothaermel and Thursby, 2005; Bercovitz and Feldman, 2006). To increase the degree to which universities take a proactive role in commercialization of innovation, many have launched or significantly grown their technology transfer offices (Autio, 1994; Mowery and Oxley, 1995; Cohen et al, 2002a, b; Colyvas et al,, 2002; Shane, 2002; Lockett et al., 2003; Wright et al., 2004; Agarwal, 2006; Bercovitz and Feldman, 2006). Similarly, numerous governments agencies also invest in research through their own laboratories, form and manage incubators, and offer grants for other public or private research entities (Wallsten, 2000; Cohen et al, 2002a, b; Salamenkaita and Salo, 2002).

Technology clusters. Clusters encompass an array of industries that are linked together in a geographical proximity through relationships among suppliers, buyers, and producers of complements (von Hippel, 1987; Dyer and Nobeoka, 2000; Schilling and Phelps, 2007). A cluster of firms with high innovation-productivity can lead to new firms starting up in the immediate vicinity and attract other firms in that area (Stuart and Sorenson, 2003), which explains the attractiveness of Silicon Valley for technology firms (Saxenian, 1990; Saxenian, 1996; Almeida and Kogut, 1999; Cohen and Fields, 1999).

Technology spillover. Technology spillover is defined as a positive externality from $R \& D$ resulting from the spread of knowledge across organization and regional boundaries (Cohen and Levinthal, 1990; Schilling, 2006) and is a function of patenting, copyrights, and trademarks (Cohen et ah, 2002a, b) in addition to the mobility of knowledge workers 
(Almeida and Kogut, 1999). It has a significant influence on innovation activities (Jaffe, 1986; Jaffe et al, 1993; Henderson et al, 1998) and increases a firm's absorptive capacity (Cohen and Levinthal, 1990).

Innovation type

Various studies have posited different taxonomies for innovations. Four more-prominent and distinct dimensions of innovation types are:

(1) product vs process innovations;

(2) radical vs incremental innovations;

(3) architectural vs component innovations; and

(4) competence-enhancing vs competence-destroying innovations.

Product vs process innovations. Product innovations are embodied in the outputs of an organization (Cooper and Kleinschmidt, 1986; Spivey et al, 1997; Danneels, 2002; Burgelman et al, 2006; Schilling, 2006). Process innovations, on the other hand, are innovations oriented toward improving the effectiveness and efficiencies of production, like reducing defect rates or improving supply-chain mechanisms (Davenport, 1993; Burgelman et al., 2006; Schilling, 2006; Klein et al, 2007; Tarafdar and Gordon, 2007). While product innovations are distinct from process innovations, the latter often helps in the attainment of the former (Burgelman et al, 2006; Schilling, 2006).

Radical us incremental innovations. Radical innovations are those that are new and totally different from prior innovations (Dahlin and Behrens, 2005; Golder et al., 2008), resulting in radically new products, services, or delivery systems (Burgelman et al, 2006). Radicalness is a function of newness and is characterized as:

- novel from past innovations and unique from present innovations; or

- having an impact on future innovations; or

- both (Dahlin and Behrens, 2005).

The most radical innovations are the ones that are new to the world and are extraordinarily different from existing products and services. Incremental innovations involve adaptations, refinements to existing products, services, or delivery systems (Burgelman et al, 2006). Sometimes radical innovations are followed by a series of incremental innovations. For example, through the introduction of the Windows-based software architecture and its subsequent mainstream penetration of the personal computer market, microsoft changed the way personal computers were adopted and adapted. It was by definition radical, and one could make the same argument for the windows-based user interface from the early Apple computers or from the prototypes at XEROX PARC that the Apple interface was partly based on. However, successive releases of the Windows operating systems can be seen as incremental innovation.

Architectural vs component-based innovations. An innovation is architectural when it changes the overall design of a system or the way components interact with each other (Christensen, 1992b; Henderson and Cockburn, 1994). An innovation is component-based or modular when it does not significantly affect the overall configuration of the system within which it is embedded (Christensen, 1992a; Henderson and Cockburn, 1994). In studying the disk-drive industry, Christensen (1992b) found that architectural innovations frequently redefine the functionality of related products and address 
fundamental product-performance needs. Such innovations have the power to change industry structure, and can often drive market innovation in that they can be aggressively deployed in emerging or remote markets, thus exhibiting an attacker's advantage. Christensen (1992a) also studied component innovations from the perspective of the disk drive industry and found that improvement in individual components benefited the firm but did not necessarily have profound influence on the broader industry.

Competence-enhancing vs competence-destroying innovations. An innovation is competence enhancing from the perspective of a firm if it builds on the firm's existing knowledge base. For example, as a firm deploys each successive generation of the Windows operating system (i.e. 3.1, 95, 98,2000, ME, XP, Vista, Windows 7), it builds not only on the technology underlying the previous operating system generation but also on its own, growing knowledge base. On the other hand, an innovation is competence destroying from the perspective of a firm if the innovation does not build on its existing competencies and instead drives new competencies. For example, the plasma screen TV supplanted the cathode ray tube (CRT).

\section{Market entry: capabilities and feasibility}

Literature on market-entry assessment concentrates on three main activities entry-time assessment, first-mover advantage, and competency analysis. The overlap between the first two means they can be discussed together.

Entry-time assessment and first-mover advantage. Research on entry timing has shown that it is a function of the margin of advantage offered by the new innovation, the state of enabling technologies, the state of complements, the state of customer expectations, threat of competitive entry, whether the industry faces increasing returns, and a firm's resources (Shaw and Shaw, 1984; Aaker and Day, 1986; Arthur, 1989; Lilien and Yoon, 1990; Makadok, 1998; Schilling, 1998; Shankar et al, 1998; Shamsie et al, 2004). Core to the discussion of entry timing is the assessment of first-mover advantage. Advantages include:

- brand loyalty and a reputation for technological leadership, preemptively capturing scarce resources, and exploiting buyer switching costs (Urban et al, 1986; Lieberman and Montgomery, 1988); and

- benefits from increasing returns due to learning-curve effects and network externalities (Katz and Shapiro, 1986; Urban et al., 1986).

Some of the disadvantages include:

- high failure rates because of considerable $R \& D$ expenses and consumer ambiguity;

- late movers can capitalize on the $R \& D$ and marketing efforts of the first movers, producing technology at lower costs and that corrects mistakes by first movers (Lieberman and Montgomery, 1988; Shankar et al., 1998); and

- first movers may also face poorly-developed infrastructure in the form of suppliers, distribution channels, and availability of complementary goods (Shaw and Shaw, 1984; Lilien and Yoon, 1990; Makadok, 1998; Shankar et al, 1998; Shamsie et al, 2004).

All of these magnify the challenge of launching new products or services.

Competency analysis. Core competencies are integrated combinations of abilities that distinguish a firm in the market place (Hamel and Prahalad, 1989; Prahalad and 
Hamel, 1989, Prahalad, 1993). The combination of resources and embedded skills that constitute competencies can require harmonizing multiple technologies across business units and can be difficult for other firms to imitate (Reed and DeFillipi, 1990; Barney, 1991). While it can be argued that competencies and capabilities are different - competencies are skill and asset interactions whereas capabilities are organizational routines (Reed and DeFillipi, 1990; Barney, 1991) - they often are used interchangeably. To avoid confusion, from this point forward in our discussions we will use the single term capability.

\section{Protection}

Like most intellectual property, innovation needs protection against duplication. Research on protection has concentrated on types of protection and its effectiveness as well as arguments as to diffusion versus protection.

Effectiveness of protection. The degree to which a firm can capture rents from its innovations is known as appropriability (Levin et al, 1987; Levin, 1988; Cohen and Levinthal, 1989; Cohen and Levinthal, 1990), which, among other things, is a function of how quickly competitors can imitate the innovation. The three primary forms of legal mechanism to protect innovations are: patents, trademarks, and copyrights (Jaffe $e$ t al, 1993; Grindley and Teece, 1997; Jaffe, 2000; Shane, 2002; Alcacer and Gittelman, 2004; Ziedonis, 2004; de Laat, 2005; Hall et al, 2005; Lecocq and Demil, 2006). Mechanisms for protecting innovations are more effective in some industries than they are in others (Levin et al, 1987; Levin, 1988; Griliches, 1990; Griliches, 1992; Lowe, 1993). In industries such as electronics and software, patents provide relatively little protection as rival firms can often work around the patent without infringing upon it (Burgelman et al, 2006; Schilling, 2006). In the biotechnology industry one typically finds that a process has created a new product (e.g. monoclonal antibodies) and it is the process that is protected, not the product itself. In such cases a firm must can reveal its products without revealing the underlying technology (Pisano and Teece, 2007). Some firms are extremely good at reverse engineering a commercialized product to understand the functionality of the components and the overall architecture. If the process is key to protecting intellectual property, reverse engineering becomes more difficult. However, the utility of process protection, and the utility of trade secrets, is diminished with the mobility of knowledge workers (Schilling and Phelps, 2007).

Protection vs diffusion. The choice between protection and diffusion is not always obvious. Most firms neither use a wholly proprietary nor a wholly open strategy (Hill, 1997; Schilling, 2000). Protecting the innovation offers a means to earn rents from innovation, which can be re-invested to further develop the technology, and to produce complementary and compatible products. It also preserves the firm's architectural control, enabling it to direct the technology's development, determine its compatibility with other goods, and prevent multiple versions of the technology from being produced by competitors (Henderson and Clark, 1990). Technology diffusion on the other hand can encourage multiple firms to promote and distribute the technology, possibly accelerating its development. Diffusion in many cases is opposite of protection, and so a middle ground is controlling a standard through licensing or having a dominant design that ensures reaping monopolistic rents in the primary and other industries (Henderson and Clark, 1990; Shane, 2002; Burgelman et al., 2006). It is useful when the firm:

- has inadequate resources to be the sole developer, producer, distributer and marketer of an innovation (Garud et al, 2002); 
- has competitors who may quickly develop their own, possibly better, version of the technology (Hill, 1992); or

- wants to ensure that its version of the technology becomes the dominant design (Hill, 1992).

\section{Development}

Three major aspects of developing an innovation are:

(1) design and manufacture: in-house or collaboration with other firms in the form of alliances or joint ventures;

(2) the process of developing the innovation; and

(3) deciding the launch form: product enhancement, new product development, wholly owned subsidiary, spin outs, or joint ventures.

Design and manufacturing in-house vs collaboration. The decision to collaborate is multidimensional and is dependent on factors such as:

- whether the firm or the collaborator has the required capabilities and resources;

- the degree to which collaboration would make proprietary technologies vulnerable to expropriation by a potential competitor;

- the importance a firm plays in controlling the development process for its innovations; and

- the degree to which a firm can access another firm's capabilities (Hitt et al., 1991; Hagedoorn, 1993; Powell et al., 1996; Ahuja, 2000a, b; Kwak, 2002; Zahra and Nielsen, 2002; Soosay and Hyland, 2008).

When a firm has the necessary capabilities to develop the product, and the managers are worried about protecting their proprietary technologies and retaining control over the development process, they typically choose to build and manufacture the innovation in-house. Often times, collaboration increases the duration from conceptualization through commercialization when too many firms are involved in the collaboration (Golder et al, 2008).

Advantages of collaboration include sharing costs and risks of development, combining complimentary skills and resources (Freeman, 1991; Powell et al, 1996; Ahuja, 2000a, b; Ahuja and Katila, 2001; Zahra and Nielsen, 2002; Brass et al., 2004; Provan et al, 2007), enabling transfer of knowledge between firms (Freeman, 1991; Gulati, 1995; Powell et al, 1996; Gulati, 1998; Gulati and Gargiulo, 1999; Gulati et al, 2000; Brass et al, 2004; Cowan and Jonard, 2004; Provan et al, 2007), and facilitating the creation of shared standards (Gulati, 1995; Powell et al, 1996; Gulati, 1998; Gulati and Gargiulo, 1999; Gulati et al, 2000; Brass et al, 2004; Litan et al, 2007; Provan et al., 2007). Collaboration, when formed through networks, can take forms such as:

- strategic alliances (Barringer and Harrison, 2000; Provan et al, 2007);

- joint ventures (Barringer and Harrison, 2000; Provan et al, 2007);

- licensing (Barringer and Harrison, 2000; Shane, 2002; Provan et al, 2007); and

- outsourcing (Barringer and Harrison, 2000; Provan et al., 2007). 
Process of developing the innovation. The literature on innovation commercialization, especially from the journals with a focus on new product development, has paid significant attention to the process of developing an innovation. Successful product development requires achievement of three objectives:

(a) maximizing fit with customer requirements;

(b) minimizing time to entry; and

(c) controlling development costs.

Some of means to achieve the three are:

- Parallel development-processes and coordination among marketing, manufacturing, and R\&D, which provide the means to meet (a), (b) and (c) (Cohen and Levinthal, 1990; Griffin and Hauser, 1992; Clark and Wheelright, 1993).

- Championing, which ensures a project's momentum and improves its access to key resources (Howell and Higgins, 1990; Markham, 2000), thereby helping (b) and (c).

- Involving customers, which can help match development projects with their requirements (Cooper, 1985; Butler, 1988; Johne and Snelson, 1988; Brown and Eisenhardt, 1995; Cristiano et al, 2001; Lilien et al., 2002), thus helping with (a).

- Involving suppliers in product development, which helps in minimizing the cost of new product design and increases the likelihood that inputs are of appropriate quality and timely, thus helping with (b) and (c).

- Some process-optimizing methods, especially for addressing (b) and (c), are stage-gate processes that enable firms to get a blueprint of new-product-development process (Cooper, 1985; Cooper and Kleinschmidt, 1986; Cohen et ah, 1998), and $\mathrm{CAD} / \mathrm{CAM}$ tools to reduce cycle times, improve product quality, and control development costs (Ebers and Lieb, 1989; Clark and Wheelright, 1993; Burgelman et al., 2006; Schilling, 2006; Litan et al, 2007).

Launch pad: spinout, subsidiary, or joint venture. An innovation can be launched in many forms. While a new product is typically launched solely by one firm, in some cases products are launched by means of spin-outs, a subsidiary, or through joint ventures. The decision between the choices is often a function of the scope of the innovation, and the risks associated with bringing it to market (Burgelman et al, 2006):

- Spinouts are where a company "splits off" a section of itself as a separate business (Lowe, 1993; Zahra, 1996; Carayannis et al., 1998; Lockett et al., 2003; Cassiman and Ueda, 2006; Richards, 2009). The common definition of a spin out is when a division of a company or organization becomes an independent business. The spin-out company takes assets, intellectual property, technology, and existing products from the parent organization (Zahra, 1996; Lockett et al, 2003; Richards, 2009). Spin outs are often created through university technology-transfer offices in conjunction with business incubators (Mian, 1997).

- A subsidiary is an entity that is controlled by a separate entity. The controlled entity is often in the form of a limited-liability company, but in some cases can be a government or state-owned enterprise. The controlling entity is called the 
parent (or the parent company) (Ghoshal and Bartlett, 1988; Zahra, 1996; Birkinshaw, 1998; Frost, 2001; Birkinshaw et al, 2005; Zahra, 2005). Two subsidiaries can be competitors in the same area. For example, Compaq, after being acquired by $\mathrm{HP}$, became a subsidiary of $\mathrm{HP}$ but also competed against $\mathrm{HP}$ in the personal-computing space.

- A joint venture is a partnership that often requires significant equity investment and the creation of separate entities (Kogut, 1988; Pennings and Harianto, 1992; Dollinger et al, 1997; Dutta and Weiss, 1997; Anand and Khanna, 2000; Lyles and Salk, 2006; Link et al, 2007). They are created for pooling resources and capabilities, and sharing risks (Soosay and Hyland, 2008). Classic examples include AutoAlliance International, between Ford and Mazda, LG-Philips Components, between LG and Philips, and Sony Ericsson, between Sony and Ericsson.

\section{Deployment}

Research on commercialization of innovation specific to deployment of an innovation to a market has concentrated on launch timing, licensing and compatibility (whether or not to make the product compatible with older versions), selecting a pricing strategy, distribution, and marketing.

Launch timing. The literature identifies factors affecting launch timing as:

- business cycle and any seasonal effects (Eliashberg and Robertson, 1988; Corey et al., 1989);

- availability of production capacity and complementary goods; and

- assessment of harvesting cash flows from existing product generations vs advantages of willingly cannibalizing existing products (Teece, 1988, 1996; Conner and Prahalad, 1996; Madhok and Tallman, 1998; Nerkar and Roberts, 2004; Song et al., 2005).

Selling out, licensing and compatibility. The decision to sell out an innovation, or license an innovation is contingent not only upon the availability of the assets required for launch within the innovating firm and the ability to appropriate the income (Teece, 1988), but also upon issues related to compatibility (Teece, 1988, 1996; Grindley and Teece, 1997) and backward compatibility, which is when products of one technological generation can work with products of the previous technological generation (Lowe, 1993; Dhebar, 1996).

Pricing. Two of the common pricing techniques discussed in the literature are market skimming and penetration pricing (Shapiro and Jackson, 1978). With market skimming, firms usually ask a high price to signal significance or to quickly recoup development costs. When achieving maximum market share is the objective then penetration pricing is the more viable strategy. Honda used this strategy to market its hybrid car at $\$ 20,000$, causing them to lose money for every sale, but it was based on the belief that the hybrid technology will be profitable in the long run and that increased sales will reduce costs through an accelerated experience-curve effect (Johng et aL, 2003).

Distribution. Firms can sell their products directly to end-users through their web sites, mail order, or can alternatively use intermediaries (Corey et al, 1989). Intermediaries provide a number of valuable roles in the supply chain, such as breaking the bulk, 
carrying inventory, logistics, selling services, and customer services (Zhang and Li, 2009). By forging relationships with distributors, and providing sales guarantees, firms can accelerate their distribution of innovations.

Marketing. Research on commercialization of innovations that focused on marketing has acknowledged that technology and marketing capabilities both were found to be significant in bringing innovations to market (Di Benedetto et al, 2008). Methods of marketing vary in attributes such as cost, reach, information content, and the ability to target particular segments (Moore, 1991; Mohr, 2001; Slater and Mohr, 2006). In addition, pre-announcements of technology, and a firm's reputation, often influence market perception associated with the innovation (Eliashberg and Robertson, 1988; Moore, 1991; Mohr, 2001; Slater and Mohr, 2006).

\section{Moving commercialization of innovation research forward}

We next build on the review done in the previous section to propose an agenda for future research on innovation commercialization. We utilize some key concepts such as radical innovations, industry boundaries, viability, future markets, and governance as a means to link the themes together.

Viability and governance: linking market entry, development and deployment Our definition of commercialization of innovations has three attributes:

(1) recognizing a market for an innovation;

(2) developing and manufacturing it into a product; and

(3) selling/distributing the product.

Where the first one is addressed through the themes of sources of innovation, as well as types of innovation and protection, the last two are essentially addressed through market entry, development and deployment themes. The literature surrounding the development theme concentrates on whether an innovation should be developed in-house or with partners, or whether it will be licensed out. Essentially, it is a question of governance form dealing with ownership of innovation with three options: development and commercialization being in-house, commercializing the innovation with others either through an alliance or via licensing, or selling it to others for them to commercialize (Zahra, 1996). Usually, commercialization is thought of in terms of the first two forms, but electing to sell an innovation also allows the firm to secure a return and, arguably, also is a form of commercialization. The choice of which form to adopt is governed by:

- the amount of profit available from commercialization; and

- the distance between a firm's existing capabilities and those required for it to be able to commercialize the innovation.

In the following discussion, we build on Teece (1986) contention that regimes of appropriability also must be in place, and on the thesis that economic gain rests critically upon a firm's ability to create and transfer technology more quickly than it is imitated.

When the returns from an innovation are thought to be high and the firm already has the requisite capabilities that are required for commercialization then logically, 
development will be through hierarchy (in-house). If the capabilities are not available internally, then sourcing them externally will reduce the firm's ability to earn rents from the innovation because suppliers of those resources will bid up prices, or they may turn into potential competitors. An alternative is to develop the capabilities internally. That requires an assessment of the effects on the current stock of knowledge and capabilities (Kogut and Zander, 1992, 1996) because long-term strategies of building new capabilities can require a tradeoff between current and future profitability. Such a choice is viable only when the firm's survival is not at stake and it has the necessary short-term cash flows to undertake learning initiatives and bear the associated risks (Kogut and Zander, 1992, 1996; Decarolis and Deeds, 1999). Conversely, too much reliance on exploiting current profitability may deter a firm from developing capabilities for the future (Stiglitz, 1987; Kogut and Zander, 1992). The decision of maintaining and developing some capabilities over others is influenced by the current knowledge of the firm and expectations from economic gain by exploring newer technologies and organizing principles into future market developments (Kogut and Zander, 1992). Thus, the promise of economic rents is usually sufficient to convince firms that developing new capabilities is a worthwhile activity (Kogut and Zander, 1992, 1996; Decarolis and Deeds, 1999). The most significant determinant of make or buy, and within firm or with suppliers, has been found to be the transaction costs associated with relying on outside suppliers (Monteverde and Teece, 1982; Walker and Weber, 1984; Kogut and Zander, 1992). It has been shown that volume and technological uncertainties, and the production capability of the buyer, reduce the advantage of buy over make, while supplier production-cost advantage, competitiveness of supplier market, and size of supplier market increases the advantage of buy over make (Walker and'Weber, 1984). While boundaries of firms are influenced by transaction costs (Williamson, 1981, 1991, 2000), performance relies mostly on owned capabilities (Kogut and Zander, 1992).

An innovation can be contracted, licensed, or developed with alliances when the firm does not have the necessary capabilities required to bring it to market, when there are uncertain cash flows, and when imitators and competitors are better positioned (Teece, 1986). Specifically, when an innovation has the potential to earn high returns, but the firm does not have the capabilities to develop the assets necessary for bringing the innovation to market, the available options are to develop the innovation with partners or license it out (Friedman, 2006). It also means that when the firm has the requisite capabilities to develop the assets that are critical for commercialization but the innovation only has the potential for low returns, commercialization via partnership also is preferable. Choosing between alliances for joint development or licensing depends upon several factors beyond profit potential and capabilities. For example, the short-term profitability needs of the firm and high investment costs (Zahra, 1996; Makadok and Walker, 2000; Kalaignanam et al., 2007), along with the existence of steep learning curves (Malerba, 1992), make a strong case for licensing.

Drawing on transaction-cost economics (Williamson, 1981, 1983, 1991, 1994, 1998), contracts with partners in developing an innovation may lead to a reduction of environmental uncertainty at the cost of behavioral uncertainty - opportunism. Such behavior occurs when an innovation, albeit novel, has uncertain market potential, or requires capabilities beyond those of the firm. A governance structure that leads to reduction of environmental uncertainty in this scenario may be more important than 
a partner being opportunistic. Mutual gains from contracts and alliance will be a less risky form of governance than in-house development.

Additionally, licensing an innovation is an option when the licensor has superior, tacit knowledge that protects the ability to secure rents, when capabilities required for commercialization are beyond those possessed by the firm, or there is pressure for immediate survival. In the case of the lack of capabilities, if the innovating firm does not license its new technology, competitors may quickly develop their own, possibly better, versions of the technology. By licensing, the innovating firm may ensure that its version of the technology becomes the dominant design (Hill, 1992; Schilling, 1998; Schilling and Phelps, 2007), thus securing an industry-wide advantage. We have already stated that advantages of collaboration include sharing costs and risks of development, combining complementary skills and resources, enabling transfer of knowledge, and facilitation of creation of shared standards. A clear example of these advantages is in the commercialization of Microsoft's Windows software. Developing complementary assets needed for commercialization of the software required sets of capabilities that were distant from what Microsoft possessed, but the partnership with Intel resulted in the emergence of the industry standard Wintel and a win for both firms.

Last, when the potential to earn profits is low and the capabilities required to develop assets required to commercialize the innovation are not available internally or through partnerships, the most logical option is to sell the innovation to another firm. Given this low-return scenario, this would be the least risky option. That, of course, assumes that the sale would not result in the buyer becoming a future competitor.

The discussions thus far raise the question:

$R Q 1$. How does the profit potential and distance between current and required capabilities, either singly or in combination, dictate the appropriate governance form for an innovation?

An innovation with low profit potential combined with the lack of capabilities necessary for commercialization will result in selling the innovation, assuming that selling it does not benefit competitors. An innovation with low profit potential combined with the capabilities necessary for commercialization will result in either developing the innovation with partners via alliances or licensing it out, assuming that the firm can use its capabilities for commercializing a more profitable innovation. However, the decision becomes much more complex when the innovation has higher profit potential. When the firm has the necessary capabilities, then the innovation likely will be developed in-house, assuming that the firm cannot use its capabilities for commercializing a more profitable innovation. If it does not have the capabilities then it can be commercialized using partnerships or, if the profit potential is sufficiently large, then it may be worthwhile spending the money to develop the necessary capabilities. Obviously, the decision is economic one. Thus, the key question becomes:

$R Q 2$. How large does the marginal profit have to be before it is worthwhile developing capabilities in-house rather than using a partnership?

This question is far more complex than its obvious revenue versus the administrative and opportunism-transaction-cost implications insofar as there are the additional issues like complements and competitive rivalry to be taken into consideration. 


\section{Radical innovations and industrial boundaries: linking innovation sources with innovation types}

While patents are means to protect innovations, they have long been considered proxies for the innovative outputs of organizations (Basberg, 1987; Grindley and Teece, 1997; Cohen et al, 2002a, b; Katila, 2002; Dahlin and Behrens, 2005; Katila and Ahuja, 2005). Patent citation counts are considered to be good estimators of the technological importance of innovations (Narin et al., 1987; Albert et al, 1991). Highly cited patents are also considered an important indicator for radical innovations (Trajtenberg, 1990). Dahlin and Behrens (2005) used patent citations to assess radicalness of innovations. In their research, a patent is radical if it is:

- both unique and novel; or

- has an impact on future technologies; or

- both.

Radical innovations have a profound influence on industry competition and company survival. Using patent-citation rates as a measure of radicalness, Hall et al. (2005) showed that the commercial value of radical innovations is significantly higher than those that are incremental. While the commercialization of innovation is key to a firm's survival (Nerkar and Shane, 2007), the commercialization of radical innovations is central to firm longevity (Burgelman and Grove, 1996; Tushman and O'Reilly, 1996, 2002; O'Reilly and Tushman, 2004). Successful radical inventions tend to provide the opportunity for the inventing firm to gain a sustainable competitive-advantage and for the subsequent generation of economic rents (Achilladelis et al., 1990; Harhoff $e t a l$, 1999). It has been observed that dominant firms value radical innovations more so than non-dominant firms (Sorescu et al, 2003), and a firm becomes long-lived when it can develop radical new products without hurting existing markets (Tushman and O'Reilly, 1996, 2002; O'Reilly and Tushman, 2004).

Using patent counts as a reasonable approximation of R\&D and innovativeness (Trajtenberg, 1987; Trajtenberg et al, 1997), Sorensen and Stuart (2000) observed that as firms grow and age, they start citing their own patents in their quest to seek future innovations. Thus, with age and size, firms tend to become more inward-looking for future innovations. Self-citation shows that the firm is looking at its old innovations and thus there likely will be overlap between technology classes of its past and current innovations, which allows it to exploit existing capabilities (Sorensen and Stuart, 2000).

Remaining within the firm's existing boundaries (i.e. within the focal-industry knowledge and existing technologies) results in little or no creation of knowledge required for the exploration that is necessary for creating novel, radical innovations (Fleming, 2001; Fleming and Sorenson, 2001). Rothaermel and Thursby (2005) found that firms are able to integrate complementary knowledge and technology by extending a firm's boundaries and tapping into innovations from outside the focal industry, which, in turn, enhances the firm's ability to create radical innovations. Integration of complementary technologies produces unique combinations through experimentation (March, 1991), and that increases the explorative ability of the firm beyond its current technology stock, resulting in novel innovations (Decarolis and Deeds, 1999; Rosenkopf and Nerkar, 2001; Hall et al, 2005). Thus, to seek complementary technologies, firms have to look beyond their boundaries. That is not limited to innovations from firms from other industries but can also include universities and research laboratories, collectively 
known as engines of innovations. Increasing the diversity of sources increases the relative novelty of knowledge a firm can access (Phelps, 2010). Given the necessary condition for radical innovation is access of dissimilar knowledge (Jansen et al, 2006; Greve, 2007), the question emerges:

$R Q 3$. How far and how much does a firm need to expand beyond the boundaries of its existing stock of knowledge in order to create radical innovations?

Radical innovations and governance: linking innovation types, market entry, and development

As far as we can determine, there is little or no research linking types of innovations with governance forms, especially launch forms. It has been argued that radicalness of innovation is important to determine whether the innovation will be commercialized by means of refinements of existing products or as a new product or a delivery system (Chandy and Tellis, 1998; Dahlin and Behrens, 2005; Chandy et al, 2006). Product enhancements or refinements do not entail creating new forms of firms, rather just product enhancements, such as Windows Service pack, or possibly a new but very similar product, such as Windows 7 (which was significantly different, but by no means radically different, from Windows XP). As already explained, radical innovations, on the other hand, entail a technology that may be drastically different from the existing stock of the firm's capabilities. Bringing such an innovation to market may involve creation of not only a new product line but potentially a new venture to drive it. There are times when not only the technology class is different but, as discussed above, also the capabilities needed to bring the innovation into the market. Too much dissimilarity may result in licensing the technology, or developing that with partners in order to bring the product into market. But, also as discussed above, if the profit potential is large enough, the commercialization may done in-house. That raises the question of what would be the best way to achieve that - integration with existing in-house activities, a separate division, or a spinout? Thus, a significant extension to the research on commercialization would be an analysis of innovation types and governance forms. Specifically:

$R Q 4$. Is radicalness sufficient to determine a change in a governance form and, if not, what are the boundary conditions?

Prima facie, the question appears straightforward, but it is worth noting, however, that firms create spinouts even if innovations are not drastically different to existing products. For instance, the engines of Scion and Lexus are not extremely different, yet they are produced by different spinouts from Toyota. Even though Scion and Lexus serve different market segments, both General Motors and Volkswagen, whose products also serve different segments, haves gone the other direction and consolidated engine manufacturing in-house with fewer engine variants.

\section{Discussions and implications}

Commercialization of innovations is a critical entrepreneurial activity that leads to economic development and growth, but remains under-researched and is therefore not as well understood as other aspects of innovation. We believe that the reasons for this are twofold. First, commercialization of innovation requires research expertise from a multitude of disciplines including management, strategy, entrepreneurship, economics, and marketing. Each of these disciplines has its own research agenda and set of 
variables that often are unique and distinct from other fields of study, making a comprehensive view almost impossible. Second, most of the work has been focused on one specific area of commercialization of innovation, such as sources of innovation, protection of intellectual property, and so forth, and identification of common themes across these diverse disciplines seemed to be the most prudent next step with this work in order to help move the research agenda forward.

Our work makes contributions to both theory and practice. From a theoretical standpoint, this paper provides two primary offerings. First, we provided a comprehensive review of the literature on innovation and commercialization that resulted in the identification of six themes of entrepreneurial activities leading to commercialization of innovations. The six themes include: sources of innovations, types of innovation, market entry (which includes capabilities and feasibility), protection, development, and deployment. Our second contribution involves identifying new areas of innovation-commercialization research. As we noted, much of the research in management, strategy, entrepreneurship, economics, and marketing clusters around a small number of themes and, often, just a single theme. We linked the themes by asking research questions:

$R Q 1$. How does profit potential and distance between current and required capabilities dictate governance form for innovation?

$R Q 2$. How large does the marginal profit have to be before it is worthwhile developing capabilities in-house rather than using a partnership?

RQ3. How far and how much does a firm need to expand beyond the boundaries of its existing stock of knowledge in order to create radical innovations? And,

$R Q 4$. Is radicalness sufficient to determine a change in a governance form and, if not, what are the boundary conditions?

We believe that this work is not only useful for future research, but it also provides some help for practitioners as well. First, and most fundamentally, our questions on commercialization and profit indicate that a careful assessment of the profit potential, vis-à-vis the firm's existing capabilities and the costs of developing new capabilities, can help reduce investments in innovations with little or no chance of financial success. In other words, financial success should not be confused with commercial success. This perspective helps force a separation between commitment to the newly developed technology and the ability to make money from it. Second, our framework highlights the need to consider the availability of partners and their capabilities before plunging into a decision to commercialize an innovation. This permits risk reduction insofar as it prevents a firm from disposing of a technology that could be developed with partners, it allows the firm to find better capabilities than those it possesses, and perhaps more cheaply, and it allows the firm to hand off development and commercialization, which then frees up time and resources for bringing other innovations to market. Third, the work identifies the need to carefully consider extending firm boundaries to include new sources of innovation - sources with product offerings whose technology base is different from the firm's current technology stock - that will be demanded in future markets. Lastly, when firms bring out products that are radically different from existing stock, we raised the question of governance form. In the absence of research that 
provides rules of thumb for implementation, we can only offer what amounts to a platitude of ensuring a strategy-structure fit.

All research projects have certain inherent limitations, as does ours. Our first assumption that the fields of management, strategy, entrepreneurship, economics, and marketing are sufficient to capture all the themes associated with entrepreneurial activities surrounding commercialization of innovation may not be valid. Inclusion of journals from science and engineering might give a deeper and richer understanding to the process. Second, it would be worth investigating whether specific disciplines had bias towards certain themes. These kinds of observations would strengthen and enrich our findings and perhaps lead to more interdisciplinary research, which clearly is needed if we are to expand our knowledge in this area. Addressing some of these issues remained outside the scope of this work, but are certainly worthy of consideration in subsequent work.

Before the research agenda set forth in this work is pursued with any vigor, the framework presented in here needs validating. That means that the assumptions and boundary conditions associated with the framework need to be tested and confirmed as being realistic. All of that achieved, we recommend a two-step approach for future research. First, conduct detailed case-studies on how firms combine aspects of each stage to bring innovations to market. Such exemplars would test for the robustness, veracity, limits, assumptions and boundary conditions of the framework. Such specific case-studies help in giving a nuanced picture to the innovation-commercialization process. For instance, while Nokia may forge alliances with universities for contracted $R \& D$ to tap innovations, Merck could invest heavily in its own R\&D, and use networks for distribution. Being a player in the GSM arena, Nokia is less dependent on cell phone service providers for market penetration than Samsung, but that means Nokia has to spend much more on branding than Samsung, whose alliance with Sprint brings co-branding opportunities. Thus, networks and alliances could come into play at different stages for different companies. Case studies can be used to look for firm-specific as well industry-specific characteristics. For example, some industries patent more than others (Levin et al., 1987). Once that is achieved, then the themes presented here can be refined into constructs and then into variables. The second stage is to empirically test the refined model using large-scale data. We anticipate that both primary and secondary data will be used.

Finally, some firms are good at innovation, but the fact remains that firms live and die by their ability to successfully bring innovations to market. We have provided a theoretical framework to address the question of what are the key elements of the commercialization-innovation pathway. While the work clearly is of relevance to practice, our intent has been to generate a framework for scholars to extend existing research on the commercialization process, and thus create an even deeper understanding of this crucial business activity.

\section{References}

Aaker, D.A. and Day, G.S. (1986), "The perils of high-growth markets", Strategic Management Journal, Vol. 7 No. 5, pp. 409-421.

Aarikka-Stenroos, L. and Sandberg, B. (2012), "From new-product development to commercialization through networks", Journal of Business Research, Vol. 65 No. 2, pp. 198-206. 
Aboulnasr, K., Narasimhan, O., Blair, E. and Chandy, R. (2008), "Competitive response to radical product innovations", Journal of Marketing, Vol. 72 No. 3, pp. 94-110.

Abrahamson, E. and Rosenkopf, L. (1993), "Institutional and competitive bandwagons: using mathematical modeling as a tool to explore innovation diffusion", Academy of Management Review, Vol. 18 No. 3, pp. 487.517.

Achilladelis, B., Schwarzkopf, A. and Cines, M. (1990), "The dynamics of technological innovation: the case of the chemical industry", Research Policy, Vol. 19 No. 1, pp. 1-34.

Acs, Z.J. and Audretsch, D.B. (1988), "Innovation in large and small firms: an empirical analysis", The American Economic Revietw, Vol. 78 No. 4, pp. 678-690.

Agarwal, A. (2006), "Engaging the inventor: exploring licensing strategies for university inventions and the role of latent knowledge", Strategic Management Journal, Vol. 27, pp. 63-79.

Ahuja, G. (2000a), "Collaboration networks, structural holes, and innovation: a longitudinal study", Administrative Science Quarterly, Vol. 45 No. 3, pp. 425-455.

Ahuja, G. (2000b), "The duality of collaboration: inducements and opportunities in the formation of interfirm linkages", Strategic Management Joumal, Vol. 21 No. 3, pp. 317-343.

Ahuja, G. and Katila, R. (2001), "Technological acquisitions and the innovation performance of acquiring firms: a longitudinal study", Strategic Management Journal, Vol. 22 No. 3 , pp. $197 \cdot 220$.

Ahuja, G. and Lampert, C.M. (2001), "Entrepreneurship in the large corporation: a longitudinal study of how established firms create breakthrough inventions", Strategic Management Journal, Vol. 22 Nos 6/7, pp. 521-543.

Albert, M.B., Avery, D., Narin, F. and McAllister, P. (1991), "Direct validation of citation counts as indicators of industrially important patents", Research Policy, Vol. 20 No. 3, pp. 251-259.

Alcacer, J. and Gittelman, M. (2004), "How do i know what you know? Patent examiners and the generation of patent citations", Review of Economics and Statistics, Vol. 88 No. 4, pp. 774-779.

Aldridge, T. and Audretsch, D.B. (2010), "Does policy influence the commercialization route? Evidence from national institutes of health funded scientists", Research Policy, Vol. 39 No. 5, pp. 583-588.

Alexiev, A.S., Jansen, J.J.P., Van den Bosch, F.A.J. and Volberda, H.W. (2010), "Top management team advice seeking and exploratory innovation: the moderating role of TMT heterogeneity", Joumal of Management Studies, Vol. 47 No. 7, pp. 1343-1364.

Allen, T.J. (1977), Managing the Flow of Technology: Technology Transfer and the Dissemination of Technological Information Within the R\&D Organization, The MIT Press, Cambridge, MA.

Almeida, P. and Kogut, B. (1997), "The exploration of technological diversity and geographic localization in innovation: start-up firms in the semiconductor industry", Small Business Economics, Vol. 9 No. 1, pp. 21-31.

Almeida, P. and Kogut, B. (1999), "Localization of knowledge and the mobility of engineers in regional networks", Management Science, Vol. 45 No. 7, pp. 905-917.

Almeida, P., Song, J. and Grant, R.M. (2002), "Are firms superior to alliances and aarkets? An empirical test of cross-border knowledge building", Organization Science, Vol. 13 №. 2, pp. 147-161.

Anand, B.N. and Khanna, T. (2000), "Do firms learn to create value? The case of alliances", Strategic Management Joumal, Vol. 21 No. 3, pp. 295-315. 
Anderson, M.H. (2008), "Social networks and the cognitive motivation to realize network opportunities: a study of managers' information gathering behaviors", Joumal of Organizational Behavior, Vol. 29 No. 1, pp. 51-78.

Andrew, J.P. and Sirkin, H.L. (2003), "Innovating for cash", Harvard Business Review, Vol. 81 No. 9, pp. 76-83.

Anokhin, S., Wincent, J. and Frishammar, J. (2011), "A conceptual framework for misfit technology commercialization", Technological Forecasting and Social Change, Vol. 78 No. 6 , pp. 1060-1071.

Anselin, L., Varga, A. and Acs, Z. (1997), "Local geographic spillovers between university research and high technology innovations", Journal of Urban Economics, Vol. 42 No. 3 , pp. $422-448$.

Arthur, W.B. (1989), "Competing technologies, increasing returns, and lock-in by historical events", The Economic Journal, Vol. 99 No. 394, pp. 116-131.

Athaide, G.A., Meyers, P.W. and Wilemon, D.L. (1996), "Seller-buyer interactions during the commercialization of technological process innovations", Joumal of Product Innovation Management, Vol. 13 No. 5, pp. 406-421.

Autio, E. (1994), "New, technology-based firms as agents of R\&D and innovation: an empirical study", Technovation, Vol. 14 No. 4, pp. 259-273.

Bantel, K.A. and Jackson, S.E. (1989), "Top management and innovations in banking: does the composition of the top team make a difference?", Strategic Management Journal, Vol. 10, Summer, pp. 107-124.

Barney, J.B. (1991), "Firm resources and sustained competitive advantage", Journal of Management, Vol. 17 No. 1, pp. 99-120.

Barringer, B. and Harrison, J. (2000), "Walking a tightrope: creating value through interorganizational relationships", Journal of Management, Vol. 26 No. 3, pp. 367-403.

Basberg, B.L. (1987), "Patents and the measurement of technological change: a survey of the literature", Research Policy, Vol. 16 Nos 2-4, pp. 131-141.

Bercovitz, J. and Feldman, M. (2006), "Entpreprenerial universities and technology transfer. a conceptual framework for understanding knowledge-based economic development", The Joumal of Technology Transfer, Vol. 31 No. 1, pp. 175-188.

Birkinshaw, J. (1998), "Corporate entrepreneurship in network organizations: how subsidiary initiative drives internal market efficiency", European Management Joumal, Vol. 16 No. 3, pp. 355-364.

Birkinshaw, J., Hood, N. and Young, S. (2005), "Subsidiary entrepreneurship, internal and external competitive forces, and subsidiary performance", International Business Review, Vol. 14 No. 2, pp. 227-248.

Birley, S., Wright, M. and Cooper, A. (2001), "Creating and growing wealth: sue birley on entrepreneurship and wealth creation (and commentary)", Academy of Management Executive, Vol. 15 No. 1, pp. 37-39.

Bock, A.J., Opsahl, T., George, G. and Gann, D.M. (2012), "The effects of culture and structure on strategic flexibility during business model innovation", Joumal of Management Studies, Vol. 49 No. 2, pp. 279-305.

Bradley, S.W., McMullen, J.S., Artz, K. and Simiyu, E.M. (2012), "Capital is not enough: innovation in developing economies", Joumal of Management Studies, Vol. 49 No. 4, p. 684.

Brass, D.J., Galaskiewicz, J. and Greve, H.R. (2004), "Taking stock of networks and organizations: a multilevel perspective", Academy of Management Joumal, Vol. 47 No. 6, pp. 795-817. 
Brouthers, K.D., Brouthers, L.E. and Wilkinson, T.J. (1995), "Strategic alliances: choose your partners", Long Range Planning, Vol. 28 No. 3, pp. 18-25.

Brown, S.L. and Eisenhardt, K.M. (1995), "Product development: past research, present findings, and future directions", Academy of Management Review, Vol. 20 No. 2, pp. 343-378.

Burgelman, R.A. and Grove, A.S. (1996), "Strategic dissonance", California Management Review, Vol. 38 No. 2, pp. 8-28.

Burgelman, R.A., Christensen, C.M. and Wheelright, S.C. (2006), Strategic Management of Technology and Innovation, McGraw-Hill/Irwin, New York, NY.

Burt, R.S. (1992), Structural Holes: The Social Structure of Competition, Harvard University Press, Cambridge, MA.

Butler, J.E. (1988), "Theories of technological innovation as useful tools for corporate strategy", Strategic Management Journal, Vol. 9 No. 1, pp. 15-29.

Carayannis, E.G., Rogers, E.M., Kurihara, K. and Allbritton, M.M. (1998), "High-technology spin-offs from government R\&D laboratories and research universities", Technovation, Vol. 18 No. 1, pp. 1-11.

Cassiman, B. and Ueda, M. (2006), "Optimal project rejection and new firm start-ups", Management Science, Vol. 52 No. 2, pp. 262-275.

Cassiman, B. and Veugelers, R. (2002), "R\&D cooperation and spillovers: some empirical evidence from Belgium", The American Economic Review, Vol. 92 No. 4, pp. 1169-1184.

Chandy, R.K and Tellis, G.J. (1998), "Organizing for radical product innovation: the overlooked role of willingness to Cannibalize", Joumal of Marketing Research, Vol. 35 No. 4, pp. $474-487$.

Chandy, R.K., Hopstaken, B., Narasimhan, O. and Prabhu, J. (2006), "From invention to innovation: conversion ability in product development", Journal of Marketing Research, Vol. 43 No. 3, pp. 1547-7193.

Chen, C.J. (2004), "The effects of knowledge attribute, alliance characteristics, and absorptive capacity on knowledge transfer performance", R\&D Management, Vol. 34 No. 3 , pp. 311-321.

Chen, $\mathrm{K}$. and Guan, J. (2011), "Mapping the innovation production process from accumulative advantage to economic outcomes: a path modeling approach", Technovation, Vol. 31 No. 7 , pp. 336-346.

Chiesa, V. and Frattini, F. (2011), "Commercializing technological innovation: learning from failures in high-tech markets", Journal of Product Innovation Management, Vol. 28 №. 4, pp. $437-454$.

Christensen, C.M. (1992a), "Exploring the limits of the technology S-curve. Part I: component technologies", Production and Operations Management, Vol. 1 No. 4, pp. 334-357.

Christensen, C.M. (1992b), "Exploring the limits of the technology S.curve. Part II: architectural technologies", Production and Operations Management, Vol. 1 No. 4, pp. 358-366.

Christensen, C.M. and Bower, J.L. (1996), "Customer power, strategic investment, and the failure of leading firms", Strategic Management Journal, Vol. 17 No. 3, pp. 197-218.

Ciabuschi, F., Dellestrand, H. and Martín, O.M. (2011), "Internal embeddedness, headquarters involvement, and innovation importance in multinational enterprises", Journal of Management Studies, Vol. 48 No. 7, pp. 1612-1639.

Clark, K.B. (1989), "Project scope and project performance: the effect of parts strategy and supplier involvement on product development", Management Science, Vol. 35 No. 10, pp. 1247-1263. 
Clark, K.B. and Wheelright, S.C. (1993), Managing New Product and Process Development, The Free Press, New York, NY.

Cohen, L.Y., Kamienski, P.W. and Espino, R.L. (1998), "Gate system focuses industrial basic research", Research Technology Management, Vol. 41 No. 4, pp. 34-37.

Cohen, S.S. and Fields, G. (1999), "Social capital and capital gains in Silicon Valley", California Management Review, Vol. 41 No. 2, p. 108.

Cohen, W.M. and Levinthal, D.A. (1989), "Innovation and learning: the two faces of R\&D", The Economic Joumal, Vol. 99 No. 397, pp. 569-596.

Cohen, W.M. and Levinthal, D.A. (1990), "Absorptive capacity: a new perspective on learning and innovation", Administrative Science Quarterly, Vol. 35 No. 1, pp. 128-152.

Cohen, W.M., Nelson, R.R. and Walsh, J.P. (2002a), "Links and impacts: the influence of public research on industrial R\&D", Management Science, Vol. 48 No. 1, pp. 1-23.

Cohen, W.M., Goto, A., Nagata, A., Nelson, R.R. and Walsh, J.P. (2002b), "R\&D spillovers, patents and the incentives to innovate in Japan and the United States", Research Policy, Vol. 31 , pp. 1349-1367.

Colyvas, J., Crow, M., Gelijns, A., Mazzoleni, R., Nelson, R.R., Rosenberg, N. and Sampat, B.N. (2002), "How do university inventions get into practice?", Management Science, Vol. 48 No. 1, pp. 61-72.

Conner, K.R. and Prahalad, C.K. (1996), "A resource-based theory of the firm: knowledge versus opportunism", Organization Science, Vol. 7 No. 5, pp. 477-501.

Cooper, R.G. (1985), "Selecting winning new product projects: using the newprod system", Journal of Product Innovation Management, Vol. 2 No. 1, pp. 34-44.

Cooper, R.G. and Kleinschmidt, E.J. (1986), "An investigation into the new product process: steps, deficiencies, and impact", Joumal of Product Innovation Management, Vol. 3, pp. 71-85.

Corey, E.R., Cespedes, F.V. and Rangan, V.K. (1989), Going to Market: Distribution Systems for Industrial Products, Harvard Business School Press, Boston, MA.

Cowan, R. and Jonard, N. (2004), "Network structure and the diffusion of knowledge", Journal of Economic Dynamics and Control, Vol. 28 No. 8, pp. 1557-1575.

Cristiano, J.J., Liker, J.K. and White, C.C. (2001), "Key factors in the successful application of qualityfunction deployment (QFD)", IEEE Transactions on Engineering Management, Vol. 48 No. 1, pp. 81-95.

Crossan, M.M. and Apaydin, M. (2010), "A multi-dimensional framework of organizational innovation: a systematic review of the literature", Joumal of Management Studies, Vol. 47 No. 6, pp. 1154-1191.

Dahlin, K.B. and Behrens, D.M. (2005), "When is an invention really radical? Defining and measuring technological radicalness", Research Policy, Vol. 34 No. 5, pp. 717-737.

Damanpour, F. (1991), "Organizational innovation: a meta-analysis of effects of determinants and moderators", Academy of Management Joumal, Vol. 34, pp. 555-590.

Damanpour, F. and Gopalakrishnan, S. (2001), "The dynamics of the adoption of product and process innovations in organizations", Journal of Management Studies, Vol. 38 No. 1, pp. $45 \cdot 65$.

Damanpour, F., Szabat, K.A. and Evan, W.M. (1989), "The relationship between types of innovation and organizational performance", Jotmal of Management Studies, Vol. 26 No. 6 , pp. 587.602 . 
Damanpour, F., Walker, R.M. and Avellaneda, C.N. (2009), "Combinative effects of innovation types and organizational performance: a longitudinal study of service organizations", Joumal of Management Studies, Vol. 46 No. 4, pp. 650-675.

Danneels, E. (2002), "The dynamics of product innovation and firm competences", Strategic Management Joumal, Vol. 23 No. 12, pp. 1095-1121.

Datta, A. (2011), "Combining networks, ambidexterity and absorptive capacity to explain commercialization of innovations: a theoretical model from review", Journal of Management \& Strategy, Vol. 2 No. 4, pp. 2-24.

Datta, A., Jessup, L. and Reed, R. (2011), "Corporate reputation for commercialization of innovation: does reputation match reality, and does innovation matter?", Technology \& Investment, Vol. 2 No. 4, pp. 256-272.

Davenport, T.H (1993), Process Innovation: Reengineering Work Through Information Technology, Harvard Business School Press, Boston, MA.

Decarolis, D.M. and Deeds, D.L. (1999), "The impact of stocks and flows of organizational knowledge on firm performance: an empirical investigation of the biotechnology industry", Strategic Management Journal, Vol. 20 No. 10, pp. 953-968.

de Laat, P.B. (2005), "Copyright or copyleft? An analysis of property regimes for software development", Research Policy, Vol. 34 No. 10, pp. 1511-1532.

Dhebar, A. (1996), "Speeding high-tech producer, meet the balking consumer", Sloan Management Review, Vol. 37 No. 2, pp. 37-49.

Di Benedetto, C.A., DeSardo, W.S. and Song, M. (2008), "Strategic capabilities and radical innovation: an empirical study in three countries", IEEE Transactions on Engineering Management, Vol. 55, pp. 420-433.

Dollinger, M.J., Golden, P.A. and Saxton, T. (1997), "The effect of reputation on the decision to joint venture", Strategic Management Journal, Vol. 18 No. 2, pp. 127-140.

Dosi, G. (1988), "Sources, procedures, and microeconomic effects of innovation", Journal of Economic Literature, Vol. 26 No. 3, pp. 1120-1171.

Dougerty, D. and Hardy, C. (1996), "Sustained product innovation in large mature organizations: overcoming innovation-to-organization problems", Academy of Management Joumal, Vol. 39 No. 5 , pp. 1120-1153.

Drazin, R. (1990), "Professionals and innovation: structural-functional versus radical-structural perspectives", Journal of Management Studies, Vol. 27 No. 3, pp. 245-263.

Dutta, S. and Weiss, A.M. (1997), "The relationship between a firm's level of technological innovativeness and its pattern of partnership agreements", Management Science, Vol. 43 No. 3, pp. 343-356.

Dyer, J.H. and Nobeoka, K. (2000), "Creating and managing a high-performance knowledge-sharing network: the Toyota case", Strategic Management Journal, Vol. 21 No. 3, pp. 345-367.

Ebers, M. and Lieb, M. (1989), "Computer integrated manufacturing as a two-edged sword", International Joumal of Operations \& Production Management, Vol. 9, pp. 69-92.

Eliashberg, J. and Robertson, T.S. (1988), "New product preannouncing behavior: a market signaling study", Joumal of Marketing Research, Vol. 25 No. 3, pp. 282-292.

Elmuti, D., Abebe, M. and Nicolosi, M. (2005), "An overview of strategic alliances between universities and corporations", Joumal of Workplace Leaming, Vol. 17 No. 1, pp. 115-129.

Fleming, L. (2001), "Recombinant uncertainty in technological search", Management Science, Vol. 47 No. 1, pp. 117-132. 
Fleming, L. and Sorenson, O. (2001), "Technology as a complex adaptive system: evidence from patent data", Research Policy, Vol. 30 No. 7, pp. 1019-1039.

Frans, P. (2012), "Commentary to 'from new-product development to commercialization through networks", Journal of Business Research, Vol. 65 No. 2, pp. 207-209.

Freeman, C. (1991), "Networks of innovators: a synthesis of research issues", Research Policy, Vol. 20 No. 5, pp. 499-514.

Friedman, Y. (2006), Building Biotechnology: Starting, Managing and Understanding Biotechnology Companies, thinkBiotech, Washington, DC.

Frost, T.S. (2001), "The geographic sources of foreign subsidiaries' innovations", Strategic Management Joumal, Vol, 22 No. 2, pp. 101-123.

Gambardella, A. and McGahan, A.M. (2010), "Business-model innovation: general purpose technologies and their implications for industry structure", Long Range Planning, Vol, 43 Nos 2/3, pp. 262-271.

Gans, J.S. and Stern, S. (2003), "The product market and the market for 'ideas': commercialization strategies for technology entrepreneurs", Research Policy, Vol. 32 No. 2, pp. 333-350.

Gans, J.S., Hsu, D.H. and Stern, S. (2002), "When does start-up innovation spur the gale of creative destruction?", The RAND Joumal of Economics, Vol. 33 No. 4, pp. 571-586.

Garud, R., Jain, S. and Kumaraswamy, A. (2002), "Institutional entrepreneurship in the sponsorship of common technological standards: the case of Sun Microsystems and Java", Academy of Management Joumal, Vol. 45 No. 1, pp. 196-214.

George, G., McGahan, A.M. and Prabhu, J. (2012), "Innovation for inclusive growth: towards a theoretical framework and a research agenda", Journal of Management Studies, Vol. 49 No. 4 , pp. $661-683$.

Ghoshal, S. and Bartlett, C.A. (1988), "Creation, adoption, and diffusion of innovations by subsidiaries of multinational corporations", Joumal of International Business Studies, Vol. 19 No. 3, pp. 365-388.

Golder, P.N., Shacham, R. and Mitra, D. (2008), "Findings - innovations' origins: when, by whom, and how are radical innovations developed?", Marketing Science, Vol. 28 No. 1, pp. 166-179.

Goldfarb, B. and Henrekson, M. (2003), "Bottom-up versus top-down policies towards the commercialization of university intellectual property", Research Policy, Vol. 32 No. 4, pp. $639-658$.

Greve, H.R. (2007), "Exploration and exploitation in product innovation", Industrial and Corporate Change, Vol. 16 No. 5, pp. 945.975.

Griffin, A. and Hauser, J.R. (1992), "Patterns of communication among marketing, engineering and manufacturing-a comparison between two new product teams", Management Science, Vol. 38 No. 3, pp. 360-373.

Griliches, Z. (1990), "Patent statistics as economic indicators: a survey", Journal of Economic Literature, Vol. 28 No. 4, pp. 1661-1707.

Griliches, Z. (1992), "The search for R\&D spillovers", The Scandinavian Joumal of Economics, Vol. 94 , pp. 29.47.

Grimpe, C. and Kaiser, U. (2010), "Balancing internal and external knowledge acquisition: the gains and pains from R\&D outsourcing", Journal of Management Studies, Vol. 47 No. 8 , pp. 1483-1509.

Grindley, P.C. and Teece, D.J. (1997), "Managing intellectual capital: licensing and cross-licensing in semiconductors and electronics", Califomia Management Review, Vol. 39 No. 2, pp. 8-41. 
Grove, A.S. (1996), Only the Paranoid Survives: Exploit the Crisis Point that Challenge Every Company and Career, Doubleday Dell Publishing Group, Inc., New York, NY.

Guan, J. and Chen, K. (2010), "Measuring the innovation production process: a cross-region empirical study of China's high-tech innovations", Technovation, Vol. 30 Nos $5 / 6$, pp. 348-358.

Gulati, R. (1995), "Social structure and alliance formation patterns: a longitudinal analysis", Administrative Science Quarterly, Vol. 40 No. 4, pp. 619-652.

Gulati, R. (1998), "Alliances and networks", Strategic Management Journal, Vol. 19 No. 4, pp. 293-317.

Gulati, R. and Gargiulo, M. (1999), "Where do interorganizational networks come from?", American Joumal of Sociology, Vol. 104 No. 5, pp. 1439-1493.

Gulati, R. and Singh, H. (1998), "The architecture of cooperation: managing coordination costs and appropriation concerns in strategic alliances", Administrative Science Quarterly, Vol. 43 No. 4 , pp. $781-814$.

Gulati, R., Nohria, N. and Zaheer, A. (2000), "Strategic networks", Strategic Management Journal, Vol. 21 No. 3, pp. 203-215.

Hagedoom, J. (1993), "Understanding the rationale of strategic technology partnering: interorganizational modes of cooperation and sectoral differences", Strategic Management Journal, Vol. 14 No. 5, pp. 371-385.

Hagedoorn, J. (2002), "Inter-firm R\&D partnerships: an overview of major trends and patterns since 1960", Research Policy, Vol. 31 No. 4, pp. 477-492.

Hall, B.H., Jaffe, A. and Trajtenberg, M. (2005), "Market value and patent citations", The RAND Journal of Economics, Vol. 36 No. 1, pp. 16-38.

Halme, M., Lindeman, S. and Linna, P. (2012), "Innovation for inclusive business: intrapreneurial bricolage in multinational corporations", Joumal of Management Studies, Vol. 49 No. 4, pp. 743-784.

Hamel, G. and Getz, G. (2004), "Funding growth in an age of austerity", Harvard Business Review, Vol. 82 Nos 7/8, pp. 76-84.

Hamel, G. and Prahalad, C.K. (1989), "Strategic intent", in Burgelman, R.A., Christensen, C.M. and Wheelright, S.C. (Eds), Strategic Management of Teclinology and Innovation, McGraw-Hill, New York, NY, p. 550.

Hanninen, S., Kauranen, I., Serkkola, A. and Ikavalko, J. (2007), "Barriers to commercialization from the 'four knowledge bases' perspective: a study of innovation in the software development sector", International Journal of Management Practice, Vol. 2 No. 3 , pp. 197-213.

Hargadon, A. and Sutton, R.I. (1997), "Technology brokering and innovation in a product development firm", Administrative Science Quarterly, Vol. 42 No. 4, pp. 716-749.

Hargadon, A. and Sutton, R.I. (2000), "Building an innovation factory", Harvard Business Review, Vol. 78 No. 3, pp. 157-166.

Harhoff, D., Narin, F., Scherer, F.M. and Vopel, K. (1999), "Citation frequency and the value of patented inventions", The Review of Economics and Statistics, Vol. 81 No. 3, pp. 511-515.

Henderson, R. and Clark, K.B. (1990), "Architectural innovation: the reconfiguration of existing product technologies and the failure of established firms", Administrative Science Quarterly, Vol. 35 No. 1, pp. 9-30.

Henderson, R. and Cockburn, I. (1994), "Measuring competence? Exploring firm effects in pharmaceutical research", Strategic Management Joumal, Vol. 15, pp. 63-84. 
Henderson, R. and Cockburn, I. (1996), "Scale, scope, and spillovers: the determinants of research productivity in drug discovery", The RAND Journal of Economics, Vol. 27 No. 1, pp. 32-59.

Henderson, R., Jaffe, A.B. and Trajtenberg, M. (1998), "Universities as a source of commercial technology: a detailed analysis of university patenting, 1965-1988", Revietv of Economics and Statistics, Vol. 80 No. 1, pp. 119-127.

Hill, C.W.L. (1992), "Strategies for exploiting technological innovations: when and when not to license", Organization Science, Vol. 3 No. 3, pp. 428-441.

Hill, C.W.L. (1997), "Establishing a standard: competitive strategy and technological standards in winner-take-all industries", The Academy of Management Executive, Vol. 11 No. 2, pp. 7-25.

Hitt, M.A., Hoskisson, R.E., Ireland, R.D. and Harrison, J.S. (1991), "Are acquisitions a poison pill for innovation?", The Executive, Vol. 5 No. 4, pp. $22-34$.

Howell, J.M. and Higgins, C.A. (1990), "Champions of technological innovation", Administrative Science Quarterly, Vol. 35 No. 2, pp. 317-341.

Huygens, M., Van Den Bosh, F.A.J., Volberda, H.W. and Baden-Fuller, C. (2001), "Co-evolution of firm capabilities and industry competition: investigating the music industry", Organization Studies, Vol. 22 No. 6, pp. 791-1011.

Iwasa, T. and Odagiri, H. (2004), "Overseas R\&D, knowledge sourcing, and patenting: an empirical study of Japanese R\&D investment in the US", Research Policy, Vol. 33 No. 5, pp. 807-828.

Jaffe, A.B. (1986), "Technological opportunity and spillovers of R\&D: evidence from firms' patents, profits, and market value", The American Economic Review, Vol. 76 No. 5 , pp. 984-1001.

Jaffe, A.B. (2000), "The US Patent system in transition: policy innovation and the innovation process", Research Policy, Vol. 29 Nos 4/5, pp. 531-557.

Jaffe, A.B., Trajtenberg, M. and Henderson, R. (1993), "Geographic localization of knowledge spillovers as evidenced by patent citations", The Quarterly Journal of Economics, Vol. 108 No. 3, pp. 577-598.

Jansen, J., Vanden Bosch, F.A.J. and Volberda, H.W. (2006), "Exploratory innovation, exploitive innovation and performance: effects of organizational antecedents and environmental moderators", Management Science, Vol. 52 No. 11, pp. 1661-1674.

Jensen, R. and Thursby, M. (2001), "Proofs and prototypes for sale: the licensing of university inventions", The American Economic Review, Vol. 91 No. 1, pp. 240-259.

Johne, F.A. and Snelson, P.A. (1988), "Success factors in product innovation: a selective review of the literature", Journal of Product Innovation Management, Vol. 5 No. 2, pp. 114-128.

Johng, J., Kang, Y., Schilling, M.A., Sul, J. and Takanashi, M. (2003), Honda Insight: Personal Hybrid, New York University Teaching Case.

Kalaignanam, K., Shankar, V. and Varadarajan, R. (2007), "Asymmetric new product development alliances: win-win or win-lose partnerships?", Management Science, Vol. 53 No. 3, pp. 357-374.

Katila, R. (2002), "New product search over time: past ideas in their prime?", Academy of Management Journal, Vol. 45 No. 5, pp. 995-1010.

Katila, R. and Ahuja, G. (2002), "Something old, something new: a longitudinal study of search behavior and new product introduction", Academy of Management Joumal, Vol. 45 No. 6 , pp. 1183-1194.

Katila, R. and Ahuja, G. (2005), "Something old, something new: a longitudinal study of search behavior and new product introduction", Academy of Management Joumal, Vol. 45, pp. 1183-1194. 
Katz, M.L. and Shapiro, C. (1985), "On the licensing of innovations", The RAND Joumal of Economics, Vol. 16 No. 4, pp. 504-520.

Katz, M.L. and Shapiro, C. (1986), "Technology adoption in the presence of network externalities", Journal of Political Economy, Vol. 94 No. 4, p. 822.

Keats, B. and Hitt, M.A. (1988), "A causal model of linkages among environmental dimensions, macro organizational characteristics, and performance", Academy of Management Joumal, Vol. 31 No. 3, pp. 570-598.

Kelm, K.M., Narayanan, V.K. and Pinches, G.E. (1995), "Shareholder value creation during R\&D innovation and commercialization stages", Academy of Management Journal, Vol. 38 No. 3 , pp. 770-786.

Kim, S.K., Lee, B.G., Park, B.S. and Oh, K.S. (2011), "The effect of R\&D, technology commercialization capabilities and innovation performance", Technological and Economic Development of Economy, Vol. 17 No. 4, pp. 563-578.

Klein, R., Rai, A. and Straub, D.W. (2007), "Competitive and cooperative positioning in supply chain logistics relationships", Decision Sciences, Vol. 38 No. 4, pp. 611-646.

Kogut, B. (1988), "Joint ventures: theoretical and empirical perspectives", Strategic Management Joumal, Vol. 9 No. 4, pp. 319-332.

Kogut, B. and Zander, U. (1992), "Knowledge of the firm, combinative capabilities, and the replication of technology", Organization Science, Vol. 3 No. 3, pp. 383-397.

Kogut, B. and Zander, U. (1996), "What firms do? Coordination, identity, and learning", Organization Science, Vol. 7 No. 5, pp. 502-518.

Koka, B.R. and Prescott, J.E. (2002), "Strategic alliances as social capital: a multidimensional view", Strategic Management Journal, Vol. 23 No. 9, pp. 795-816.

Kortum, S. and Lerner, J. (2000), "Assessing the contribution of venture capital to innovation", The RAND Journal of Economics, Vol. 31 No. 4, pp. 674-692.

Kulatilaka, N. and Lin, L. (2006), "Impact of licensing on investment and financing of technology development", Management Science, Vol. 52 No. 12, pp. 1824-1837.

Kumar, N., Scheer, L. and Kotler, P. (2000), "From market driven to market driving", European Management Joumal, Vol. 18 No. 2, pp. 129-142.

Kutvonen, A. (2011), "Strategic application of outbound open innovation", European Joumal of Innovation Management, Vol. 14 No. 4, pp. 460-474.

Kwak, M. (2002), "What's the best commercialization strategy for startups?", Sloan Management Review, Vol. 48 No. 3, p. 10.

Lane, P.J. and Lubatkin, M. (1998), "Relative absorptive capacity and interorganizational learning", Strategic Management Joumal, Vol. 19 No. 5, pp. $461-477$.

Lecocq, X. and Demil, B. (2006), "Strategizing industry structure: the case of open systems in a low-tech industry", Strategic Management Joumal, Vol. 27 No. 9, pp. 891-898.

Levin, R.C. (1988), "Appropriability, R\&D spending, and technological performance", The American Economic Review, Vol. 78 No. 2, pp. 424-428.

Levin, R.C., Klevorick, A.K., Nelson, R.R., Winter, S.G., Gilbert, R. and Griliches, Z. (1987), "Appropriating the returns from industrial research and development", Brookings Papers on Economic Activity, Vol. 1987 No. 3, pp. 783-831.

Lieberman, M.B. and Montgomery, D.B. (1988), "First-mover advantages", Strategic Management Joumal, Vol, 9, pp. 41-58. 
Lilien, G.L., Morrison, P.D., Searls, K., Sonnack, M. and von Hippel, E. (2002), "Performance assessment of the lead user idea-generation process for new product development", Management Science, Vol. 48 No. 8, pp. 1042-1059.

Lilien, G.L. and Yoon, E. (1990), "The timing of competitive market entry: an exploratory study of new industrial products", Management Science, Vol. 36 No. 5, pp. 568-585.

Link, A.N., Siegel, D.S. and Bozeman, B. (2007), "An empirical analysis of the propensity of academics to engage in informal university technology transfer", Industrial and Corporate Change, Vol. 16 No. 4, pp. 641-655.

Link, A.N., Siegel, D.S. and Van Fleet, D.D. (2011), "Public science and public innovation: assessing the relationship between patenting at US National Laboratories and the Bayh-Dole Act", Research Policy, Vol. 40 No. 8, pp. 1094-1099.

Litan, R.E., Mitchell, L. and Reedy, E.J. (2007), "Commercializing university innovations: alternative approaches", Innovation Policy and the Economy, Vol. 8, pp. 31-57.

Lo, C.-C., Wang, C.-h., Chien, P.Y. and Hung, C.-W. (2012), "An empirical study of commercialization performance on nanoproducts", Technovation, Vol. 32 Nos $3 / 4$, pp. $168-178$.

Lockett, A., Wright, M. and Franklin, S. (2003), 'Technology transfer and universities' spin-out strategies", Small Business Economics, Vol. 20 No. 2, pp. 185-200.

Lowe, J. (1993), "Commercialization of university research: a policy perspective", Technology Analysis \& Strategic Management, Vol. 5 No. 1, pp. 27-37.

Lyles, M.A. and Salk, J.E. (2006), "Knowledge acquisition from foreign parents in international joint ventures: an empirical examination in the Hungarian context", Academy of International Business, Vol. 38 No. 1, pp. 3-18.

Lynn, L.H., Mohan Reddy, N. and Aram, J.D. (1996), "Linking technology and institutions: the innovation community framework", Research Policy, Vol. 25 No. 1, pp. 91-106.

McCoy, A.P., Badinelli, R., Koebel, T.C. and Thabet, W. (2010), "Concurrent commercialization and new-product adoption for construction products", European Journal of Imnovation Management, Vol. 13 No. 2, pp. 222-243.

McGrath, R.G., Tsai, M.H., Venkataraman, S. and MacMillan, I.C. (1996), "Innovation, competitive advantage and rent: a model and test", Management Science, Vol. 42 No. 3 , pp. 389-403.

Madhok, A. and Tallman, S.B. (1998), "Resources, transactions and rents: managing value through interfirm collaborative relationships", Organization Science, Vol. 9 No. 3 , pp. 326-339.

Makadok, R. (1998), "Can first-mover and early-mover advantages be sustained in an industry with low barriers to entry/imitation?", Strategic Management Journal, Vol. 19 No. 7 , pp. 683-696.

Makadok, R. and Walker, G. (2000), "Identifying a distinctive competence: forecasting ability in the money fund industry", Strategic Management Journal, Vol. 21 No. 8, pp. 853-864.

Malerba, F. (1992), "Leaming by firms and incremental technical change", Economic Joumal, Vol. 102, pp. 845-859.

March, J.G. (1991), "Exploration and exploitation in organizational leaming", Organization Science, Vol. 2 No. 1, pp. 71-87.

Markham, S.K. (2000), "Corporate championing and antagonism as forms of political behavior: an R\&D perspective", Organization Science, Vol. 11 No. 4, pp. 429-447. 
Martinez-Sánchez, A., Vela-Jiménez, M.-J., Pérez-Pérez, M. and de-Luis-Carnicer, P. (2011), "The dynamics of labour flexibility: relationships between employment type and innovativeness", Journal of Management Studies, Vol. 48 No. 4, pp. 715-736.

Mascarenhas, B. (1991), "Adoption, discontinuation, and retention of a capital good innovation", Journal of Management Studies, Vol. 28 No. 1, pp. 91-101.

Mellahi, K. and Wilkinson, A. (2010), "A study of the association between level of slack reduction following downsizing and innovation output", Journal of Management Studies, Vol. 47 No. 3, pp. $483-508$.

Mian, S.A. (1997), "Assessing and managing the university technology business incubator: an integrative framework", Journal of Business Venturing, Vol. 12 No. 4, pp. 251-285.

Milliken, FJ. (1987), "Three types of perceived uncertainty about the environment: state, effect, and response uncertainty", Academy of Management Review, Vol. 12 No. 1, pp. 133-143.

Mitchell, W. (1989), "Whether and when? Probability and timing of incumbents' entry into emerging industrial subfields", Administrative Science Quarterly, Vol. 34 No. 2, pp. 208-230.

Mohr, JJ. (2001), Marketing of High-Technology of Porducts and Innovations, Prentice-Hall, Upper Saddle River, NJ.

Monteverde, K. and Teece, D.J. (1982), "Supplier switching costs and vertical integration in the automobile industry", The Bell Journal of Economics, Vol. 13 No. 1, pp. 206-213.

Moore, G.A. (1991), Crossing the Chasm. Marketing and Selling Disruptive Products to Mainstream Customers, Harper Business, New York, NY.

Moore, G.A. (2000), Living on the Fault Line. Managing for Shareholder Value in the Age of the Internet, Harper Business, New York, NY.

Morgan, R.E. and Berthon, P. (2008), "Market orientation, generative learning, innovation strategy and business performance inter-relationships in bioscience firms", Journal of Management Studies, Vol, 45 No. 8, pp. 1329-1353.

Mowery, D.C. and Oxley, J.E. (1995), "Inward technology transfer and competitiveness: the role of national innovation systems", Camb. J. Econt., Vol. 19 No. 1, pp. 67.93.

Mowery, D.C., Oxley, J.E. and Silverman, B.S. (1996), "Strategic alliances and interfirm knowledge transfer", Strategic Management Journal, Vol. 17, pp. 77-91.

Nambisan, S. and Sawhney, M. (2007), "A buyer's guide to the innovation bazar", Harvard Business Review, Vol. 85 No. 6.

Narayanan, V.K., Pinches, G.E., Kelm, K.M. and Lander, D.M. (2000), "The influence of voluntarily disclosed qualitative information", Strategic Management Journal, Vol. 21 No. 7, pp. 707-722.

Narin, F., Noma, E. and Perry, R. (1987), "Patents as indicators of corporate technological strength", Research Policy, Vol. 16 Nos 2-4, pp. 143-155.

Nerkar, A. and Roberts, P.W. (2004), "Technological and product-market experience and the success of new product introductions in the pharmaceutical industry", Strategic Management Joumal, Vol. 25 Nos 8/9, pp. 779-799.

Nerkar, A. and Shane, S. (2007), "Determinants of invention commercialization: an empirical examination of academically sourced inventions", Strategic Management Journal, Vol. 28 No. 11, pp. 1155-1166.

Nerkar, A.A., McGrath, R.G. and MacMillan, I.C. (1996), "Three facets of satisfaction and their influence on the performance of innovation teams", Journal of Business Venturing, Vol. 11 No. 3, pp. 167-188. 
Numprasertchai, S. and Igel, B. (2005), "Managing knowledge through collaboration: multiple case studies of managing research in university laboratories in Thailand", Technovation, Vol. 25 No. 10, pp. 1173-1182.

O'Reilly, C.A. and Tushman, M.L. (2004), "Ambidextrous organization", Harvard Business Review, Vol. 82 No. 4, pp. 71-81.

Penner-Hahn, J. and Shaver, J.M. (2005), "Does international research and development increase patent output? An analysis of Japanese pharmaceutical firms", Strategic Management Journal, Vol. 26 No. 2, pp. 121-140.

Pennings, J.M. and Harianto, F. (1992), "Technological networking and innovation implementation", Organization Science, Vol. 3 No. 3, pp. 356-382.

Phelps, C. (2010), "A longitudinal study of the influence of alliance network structure and composition on firm exploratory innovation", Academy of Management Joumal, Vol. 53 No. 4, pp. 890-913.

Pisano, G.P. and Teece, D.J. (2007), "How to capture value from innovation: shaping intellectual property and industry architecture?", Califormia Management Review, Vol. 50 No. 1, pp. 278-296.

Powell, W.W., Koput, K.W. and Smith-Doerr, L. (1996), "Interorganizational collaboration and the locus of innovation: networks of learning in biotechnology", Administrative Science Quarterly, Vol. 41 No. 1, pp. 116-145.

Prahalad, C.K. (1993), "The role of core competencies in the corporation", Research Technology Management, Vol. 36 No. 6, p. 40.

Prahalad, C.K. and Hamel, G.(1989), "The core competence of the corporation", in Burgelman, R.A., Christensen, C.M. and Wheelright, S.C. (Eds), Strategic Management of Technology and Innovation, McGraw-Hill, New York, NY, p. 102.

Provan, K.G., Fish, A. and Sydow, J. (2007), "Interorganizational networks at the network level: a review of empirical literature on whole networks", Journal of Management, Vol. 33 №. 3 , pp. 479-516.

Ragatz, G.L., Handfield, R.B. and Scannell, T.V. (1997), "Success factors for integrating suppliers into new product development", Joumal of Product Imnovation Management, Vol. 14, pp. 190-202.

Reed, R. and DeFillipi, R.J. (1990), "Causal ambiguity, barriers to imitation, and sustainable competitive advantage", Academy of Management Review, Vol. 15 No. 1, pp. 88-102.

Rice, M., Kelley, D., Peters, L. and O'Connor, G.C. (2001), "Radical innovation: triggering initiation of opportunity recognition and evaluation", R\&D Management, Vol. 31 No. 4, pp. 409-420.

Richards, G. (2009), Spin-Outs: Creating Businesses from University Intellectual Property, Harriman House, London.

Roberts, E.B. (2001), "Benchmarking global strategic management of technology", Research-Technology Management, Vol. 44 No. 2, pp. 25-36.

Rohrbeck, R., Döhler, M. and Arnold, H. (2009), "Creating growth with externalization of R\&D results - the spin-along approach", Global Business and Organizational Excellence, Vol. 28 No. 4, pp. 44-51.

Ron, A. and Levinthal, D. (2001), "Demand heterogeneity and technology evolution: implications for product and process innovation", Management Science, Vol. 47 No. 5, pp. 611.628.

Rosenkopf, L. and Almeida, P. (2003), "Overcoming local search through alliances and mobility", Management Science, Vol. 49 No. 6, pp. 751-766. 
Rosenkopf, L. and Nerkar, A. (2001), "Beyond local search: boundary-spanning, exploration, and impact in the optical disk industry", Strategic Management Journal, Vol. 22 No. 4, pp. 287-306.

Rothaermel, F.T. and Thursby, M. (2005), "University-incubator firm knowledge flows: assessing their impact on incubator firm performance", Research Policy, Vol. 34 No. 3, pp. 305-320.

Salaman, G. and Storey, J. (2002), "Managers' theories about the process of innovation", Journal of Management Studies, Vol. 39 No. 2, pp. 147-165.

Salamenkaita, J.P. and Salo, P. (2002), "Rationales for govemment interventions in the commercialization of new technologies", Technology Analysis \& Strategic Management. Vol. 14 No. 2, pp. 183-200.

Saxenian, A.L. (1990), "Regional networks and the resurgence of Silicon Valley", California Management Revietv, Vol. 33 No. 1, pp. 89-112.

Saxenian, A.L. (1996), Regional Advantage: Culture and Competition in Silicon Valley and Route 128, Harvard University Press, Cambridge, MA.

Schendel, D. and Hill, M.A. (2007), "Comments from editors: introduction to volume 1", Strategic Entrepreneurship Joumal, Vol. I Nos 1/2, pp. 1-7.

Schilling, M.A. (1998), "Technological lockout: an integrative model of the economic and strategic factors driving technology success and failure", The Academy of Management Review, Vol. 23 No. 2, pp. 267-284.

Schilling, M.A. (2000), "Toward a general modular systems theory and its application to interfirm product modularity", The Academy of Management Review, Vol. 25 No. 2, pp. $312-334$.

Schilling, M.A. (2006), Strategic Management of Technological Innovation, McGraw-Hill/Irwin, New York, NY.

Schilling, M.A. and Phelps, C.C. (2007), "Interfirm collaboration networks: the impact of large-scale network structure on firm innovation", Management Science, Vol. 53 No. 7, pp. 1113-1126.

Schroll, A. and Mild, A. (2011), "Open innovation modes and the role of internal R\&D", European Joumal of Innovation Management, Vol. 14 No. 4, pp. 475-495.

Scott, S.G. and Bruce, R.A. (1994), "Determinants of innovative behavior: a path model of individual innovation in the workplace", The Academy of Management Joumal, Vol. 37 No. 3, pp. 580-607.

Seppanen, V. and Skates, M. (2001), "Managing relationships and competence to stay market oriented: the case of a Finnish contract research organization", American Marketing Association, Conference Proceedings.

Shamsie, J., Phelps, C. and Kuperman, J. (2004), "Better late than never: a study of late entrants in household electrical equipment", Strategic Management Journal, Vol. 25 No. 1, pp. 69.84.

Shane, S. (2002), "Selling university technology: patterns from mit", Management Science, Vol. 48 No. 1, pp. 122-137.

Shankar, V., Carpenter, G.S. and Krishnamurthi, L. (1998), "Late mover advantage: how innovative late entrants outsell pioneers", Joumal of Marketing Research, Vol. 35 No. 1, pp. 5470.

Shapiro, B. and Jackson, B. (1978), "Industrial pricing to meet customer needs", Harvard Business Review, Vol. 56, pp. 119-127.

Shaw, R.W. and Shaw, S.A. (1984), "Late entry, market shares and competitive survival: the case of synthetic fibers", Managerial and Decision Economics, Vol. 5 No. 2, pp. 72.79. 
Simmonds, K. (1986), "Marketing as innovation the eighth paradigm", Journal of Management Studies, Vol. 23 No. 5, pp. 479-500.

Slater, S.F. and Mohr, J.J. (2006), "Successful development and commercialization of technological innovation: insights based on strategy type",Journal of Product Innovation Management. Vol. 23 No. 1, pp. 26-33.

Song, M., Droge, C., Hanvanich, S. and Calantone, R. (2005), "Marketing and technology resource complementarity: an analysis of their interaction effect in two environmental contexts", Strategic Management Journal, Vol. 26 No. 3, pp. 259-276.

Soosay, C. and Hyland, P. (2008), "Exploration and exploitation: the interplay between knowledge and continuous innovation", International Joumal of Technology Management, Vol. 42, pp. 20-35.

Sorensen, J.B. and Stuart, T.E. (2000), "Aging, obsolescence, and organizational innovation", Administrative Science Quarterly, Vol. 45 No. 1, pp. 81-112.

Sorescu, A.B., Chandy, R.K. and Prabhu, J.C. (2003), "Sources and financial consequences of radical innovation: insights from pharmaceuticals", The Journal of Marketing, Vol. 67 No. 4 , pp. 82-102.

Spivey, A.W., Munson, M.J. and Wolcottl, J.H. (1997), "Improving the new product development process: a fractal paradigm for high-technology products", Joumal of Product Innovation Management, Vol. 14 No. 3, pp. 203-218.

Stevens, G.A. and Burley, J. (1997), "3,000 raw ideas=1 commercial success!", Research Technology Management, Vol. 40 No. 3, pp. 16-27.

Stiglitz, J.E. (1987), "The causes and consequences of the dependence of quality on price",Journal of Economic Literature, Vol. 25 No. 1, pp. 1-48.

Stuart, T. and Sorenson, O. (2003), "The geography of opportunity: spatial heterogeneity in founding rates and the performance of biotechnology firms", Research Policy, Vol. 32 No. 2, pp. 229-253.

Tallman, S. and Li, J. (1996), "Effects of international diversity and product diversity on the performance of multinational firms", Academy of Management Journal, Vol. 39 No. 1, pp. 179.196.

Tarafdar, M. and Gordon, S.R. (2007), "Understanding the influence of information systems competencies on process innovation: a resource-based view", Journal of Strategic Information Systems, Vol. 16, pp. 353-392.

Teece, D.J. (1986), "Profiting from technological innovation: implication for integration, collaboration, licensing and public policy", Research Policy, Vol. 15 No. 6, pp. 285-305.

Teece, D.J. (1988), "Capturing value from technological innovation: integration, strategic partnering, and licensing decisions", Interfaces, Vol. 18 No. 3, pp. 46-61.

Teece, D.J. (1996), "Firm organization, industrial structure, and technological innovation", Joternal of Economic Behavior \& Organization, Vol. 31 No. 2, pp. 193-224.

Teece, D.J., Pisano, G. and Shuen, A. (1997), "Dynamic capabilities and strategic management", Strategic Management Jottrnal, Vol. 18 No. 7, pp. 509.533.

Trajtenberg, M. (1987), "Patents, citations and innovations: tracing the links", NBER Working Paper Series, Vol. w2457.

Trajtenberg, M. (1990), "A penny for your quotes: patent citations and the value of innovations", The RAND Journal of Economics, Vol. 21 No. 1, pp. 172-187.

Trajtenberg, M., Henderson, R. and Jaffe, A. (1997), "University versus corporate patents: a window on the basicness of invention", Economics of Innovation and New Technology, Vol. 19, p. 50. 
Tushman, M.L. and O'Reilly, C.A. (1996), "Ambidextrous organizations: managing evolutionary and revolutionary change", Califormia Management Review, Vol. 38 No. 4, pp. 8-30.

Tushman, M.L. and O'Reilly, C.A. (2002), Winning Through Innovation: A Practical Guide to Leading Organizational Change and Renewal, Harvard Business School Press, Boston, MA.

Urban, G.L., Carter, T., Gaskin, S. and Mucha, Z. (1986), "Market share rewards to pioneering brands: an empirical analysis and strategic implications", Management Science, Vol. 32 No. 6, pp. 645-659.

Vaccaro, I.G., Jansen, J.J.P., Van Den Bosch, F.A.J. and Volberda, H.W. (2012), "Management innovation and leadership: the moderating role of organizational size", Journal of Management Studies, Vol, 49 No. 1, pp. $28-51$.

Veugelers, R. (1997), “Internal R\&D expenditures and external technology sourcing”, Research Policy, Vol. 26, pp. 303-315.

von Hippel, E. (1987), "Cooperation between rivals: informal know-how trading", Research Policy, Vol. 16 No. 6, pp. 291-302.

Wade, J. (1996), "A community-level analysis of sources and rates of technological variation in the microprocessor market", The Academy of Management Joumal, Vol. 39 No. 5, pp. 1218-1244.

Wade, M. and Hulland, J. (2004), "The resource based view and information systems research: review, extension, suggestions for future research", MIS Quarterly, Vol. 28 No. 1, pp. 107-142.

Walker, G. and Weber, D. (1984), "A transaction cost approach to make-or-buy decisions", Administrative Science Quarterly, Vol. 29 No. 3, pp. 373-391.

Wallsten, S.J. (2000), "The effects of government-industry R\&D programs on private R\&D: the case of the small business innovation research program", The RAND Journal of Economics, Vol. 31 No. 1, pp. 82-100.

Williamson, O.E. (1981), "The economics of organization: the transaction cost approach", The American Joumal of Sociology, Vol. 87 No. 3, pp. 548-577.

Williamson, O.E. (1983), Markets and Hierarchies: Analysis and Antitrtst Implications, Reprint edition, The Free Press, New York, NY.

Williamson, O.E. (1991), "Comparative economic organization: the analysis of discrete structural alternatives", Administrative Science Quarterly, Vol. 36 No. 2, pp. 269-296.

Williamson, O.E. (1994), "Visible and invisible governance", The American Economic Revietv, Vol. 84 No. 2, pp. 323-326.

Williamson, O.E. (1998), "The institutions of governance", The American Economic Review, Vol. 88 No. 2, pp. $75-79$.

Williamson, O.E. (2000), "The new institutional economics: taking stock, looking ahead", Joumal of Economic Literature, Vol. 38 No. 3, pp. 595.613.

Wolfe, R.A. (1994), "Organizational innovation: review, critique, and suggested research directions", Journal of Management Studies, Vol. 31 No. 3, pp. 405-431.

Woodman, R.W., Sawyer, J.E. and Griffin, R.W. (1993), "Toward a theory of organizational creativity", The Academy of Management Revietw, Vol. 18 No. 2, pp. 293.321.

Wright, M., Birley, S. and Mosey, S. (2004), "Entrepreneurship and university technology transfer", The Joumal of Technology Transfer, Vol. 29 No. 3, pp. 235-246.

Yoon, E. and Lilien, G.L. (1988), "Characteristics of the industrial distributors innovation activities: an exploratory study", Joumal of Product Innovation Management, Vol. 5, pp. $227 \cdot 240$. 
Zahra, S.A. (1996), "Goverance, ownership, and corporate entrepreneurship: the moderating impact of industry technological opportunities", Academy of Management Joumal, Vol. 39 No. 6 , pp. 1713-1735.

Zahra, S.A. (2005), "A theory of international new ventures: a decade of research", Joumal of International Business Studies, Vol. 36 No. 1, pp. 20-28.

Zahra, S.A. and George, G. (2002), "Absorptive capacity: a review, reconceptualization, and extension", Academy of Management Review, Vol. 27 No. 2, pp. 185-203.

Zahra, S.A. and Nielsen, A.P. (2002), "Sources of capabilities, integration and technology commercialization", Strategic Management Journal, Vol. 23 No. 5, pp. 377-398.

Zhang, Y. and Li, H. (2009), "Innovation search of new ventures in a technology cluster: the role of ties with service intermediaries", Strategic Management Journal, Vol. 31, pp. 88-109.

Ziedonis, R.H. (2004), "Don't fence me in: fragmented markets for technology and the patent acquisition strategies of firms", Management Science, Vol. 50 No. 6, pp. 804-820.

\section{Further reading}

Datta, A. (2011a), "An integrative model to explain the ability to commercialize innovations: linking networks, absorptive capacity, ambidexterity and environmental factors", Journal of Management \& Strategy, Vol. 2 No. 2, pp. 2-22.

Datta, A. (2011b), "Information technology and firm innovations: a review and extension explicating the role of networks, capabilities, and commercialization of innovation", International Joumal of Innovation in Digital Economy, Vol. 2 No. 4, pp. 45-63.

Datta, A. (2011c), "Information technology capability, knowledge assets and firm innovation: a theoretical framework for conceptualizing the role of information technology in firm innovation", International Journal of Strategic Information Technology and Applications, Vol. 2 No. 3, pp. 9-26.

Link, A.N., Siegel, D.S. and Bozeman, B. (2007), "An empirical analysis of the propensity of academics to engage in informal university technology transfer", Ind. Corp. Change, Vol. 16 No. 4 , pp. $641-655$. 